\title{
Depositional Conditions of Cretaceous Ironstones Deposit in the Chulym-Yenisey Basin (Western Siberia)
}

\author{
Maxim Rudmin ${ }^{1,2, *(\mathbb{D}, \text { Santanu Banerjee }}{ }^{3} \mathbb{D}$, Aigerim Dauletova $^{1}$ and Aleksey Ruban ${ }^{1}$ \\ 1 Division for Geology, Tomsk Polytechnic University, 634050 Tomsk, Russia; ikerimdb@gmail.com (A.D.); \\ ruban@tpu.ru (A.R.) \\ 2 Laboratory of Sedimentology and Paleobiosphere Evolution, University of Tyumen, 625003 Tyumen, Russia \\ 3 Department of Earth Sciences, Indian Institute of Technology Bombay, Mumbai 400076, Maharashtra, India; \\ santanu@iitb.ac.in \\ * Correspondence: rudminma@tpu.ru; Tel.: +7-8-3822-60-62-45
}

check for

updates

Citation: Rudmin, M.; Banerjee, S.;

Dauletova, A.; Ruban, A.

Depositional Conditions of

Cretaceous Ironstones Deposit

in the Chulym-Yenisey Basin

(Western Siberia). Minerals 2021, 11,

1008. https://doi.org/10.3390/

$\min 11091008$

Academic Editors: Georgia Pe-Piper and Luca Aldega

Received: 13 July 2021

Accepted: 14 September 2021

Published: 16 September 2021

Publisher's Note: MDPI stays neutral with regard to jurisdictional claims in published maps and institutional affiliations.

Copyright: (C) 2021 by the authors Licensee MDPI, Basel, Switzerland. This article is an open access article distributed under the terms and conditions of the Creative Commons Attribution (CC BY) license (https:/ / creativecommons.org/licenses/by/ $4.0 /)$.

\begin{abstract}
This study reconstructs the depositional conditions of ironstones within the ChulymYenisey basin and assesses the iron source. The detrital minerals of the studied deposits include quartz and feldspar. The authigenic minerals are goethite, siderite, aragonite, dolomite, calcite, apatite, barite, and pyrite. The clay components include minerals of the chlorite group (possible chamosite), nontronite, kaolinite, illite, and beidellite. Local bacterial sulfate reduction led to the formation of pyrite framboids in siltstone layers. The subsequent diagenetic iron reduction promoted the formation of chamosite from siderite. The goethite precipitation occurred in an oxidic aqueous environment. The Cretaceous continental sediments of the Ilek and Kia Formations of the Chulym-Yenisei depression consist of fine- and medium-grained, cross-stratified, poorly sorted litho-feldspatho-quartzose sandstones of fluvial channel origin alternating with bluish-gray siltstones and ironstones of floodplain-lacustrine-bog origin. Thin layers of iron-bearing rocks within siltstones formed in meromictic waters. The changes in geochemical proxies demonstrate fluctuations of paleoenvironmental conditions within the Cretaceous sequence. Siltstones and sandstones formed under humid and arid conditions, respectively. The primary iron source for sediments of the Chulym-Yenisey depression was determined as volcanogenic and igneous rocks of the Altai-Sayan mountainous region.
\end{abstract}

Keywords: ironstones; continental deposits; authigenic minerals; iron geochemical cycle; paleoenvironmental conditions; iron source; Late Cretaceous

\section{Introduction}

Ironstones are sedimentary rocks consisting of at least $15 \%$ iron; they occur predominantly in the Phanerozoic and belong to two categories based on the sedimentary environment: marine and continental deposits [1-4]. Marine ironstones are distinctively non-cherty, sandy to clayey siliciclastic or siliciclastic-carbonate sedimentary rocks with more than $5 \%$ of iron-rich ooids or more than $15 \%$ of iron [3-6]. Factors controlling the origin, distribution, and sources of iron are still being debated [3,7-12]. Continental ironstones [13-16] are comparatively rarer, but they are crucial for understanding the biogeochemical iron cycle in different periods of geological time $[17,18]$. These ironstones, known as channel iron deposits, occur in Oligocene sediments of Turgay and Aral regions of Kazakhstan [19-21] and in Miocene age paleochannel sediments in the Pilbara region of Western Australia [1,16,22,23]. Continental ironstones are predominantly of fluvial, alluvial, or lacustrine origin, including the entire spectrum from ferruginous mudstone to conglomerate [1,22,24]. A thorough investigation of these deposits is essential for the reconstruction of paleoenvironmental conditions of mineral formation $[18,25,26]$, in addition to their commercial importance $[22,27,28]$. Fluvial, alluvial, lacustrine, or bog ironstones remain poorly understood, although they bear signs of global geological events [29-33]. 
The lack of ferruginous conditions in the modern continental systems is a challenge for understanding the iron biogeochemical cycle in past times [18]. The depositional conditions in the Upper Cretaceous deposits are likely to shed light on the iron geochemical cycle of epicontinental basins and adjacent continental plains.

Deposition of iron-rich sediments within the Chulym-Yenisey depression took place in a continental setting during the Late Mesozoic [34]. At the same time, ooidal ironstones deposits formed in the neighboring marine epicontinental basin of Western Siberia [35,36]. The continental Chulym-Yenisey basin was a coastal plain where a huge volume of iron was accumulated along the West Siberian coast [36-38] bordering the mountainous regions. The Upper Cretaceous of the eastern margin of Western Siberia includes large reserves of marine ironstone [39-43]. A few researchers considered the terranes of the West Siberian plate rather than the mountainous regions of the Altai-Sayan as the probable iron source [44-49]. However, a combined mineralogical and geochemical investigation of the Cretaceous iron-bearing sequence of the Chulym-Yenisey depression sheds new light on the problem indicating an alternative source for the iron-rich sediments.

This study investigates petrography, mineralogy, and geochemistry of a Cretaceous iron-rich deposit in the Chulym-Yenisey depression and reconstructs its paleoenvironmental and paleoclimatic conditions.

\section{Geological Background}

The studied area of the Chulym-Yenisey basin (Figure 1) is a part of the West Siberian plate that merged with the northeastern part of the Altai-Sayan region. The Chulym-Yenisei depression [36] is dissected by numerous rivers and streams with major swamps. The sedimentary column is subdivided into Jurassic, Cretaceous, and Cenozoic units. The Cretaceous succession unconformably overlies the Jurassic deposits and is composed of variegated fine-grained sandy-argillaceous-silty lacustrine-alluvial facies with occurrences of ironstone and bauxite.

The units of the Altai-Sayan fold zone covers the Early Paleozoic structures of the Kuznetsk Alatau associated with extensive accretionary granitoids. Scientists defined a structural unconformity and a sedimentation break at the boundary of the early and late Caledonian stages $[50,51]$. 


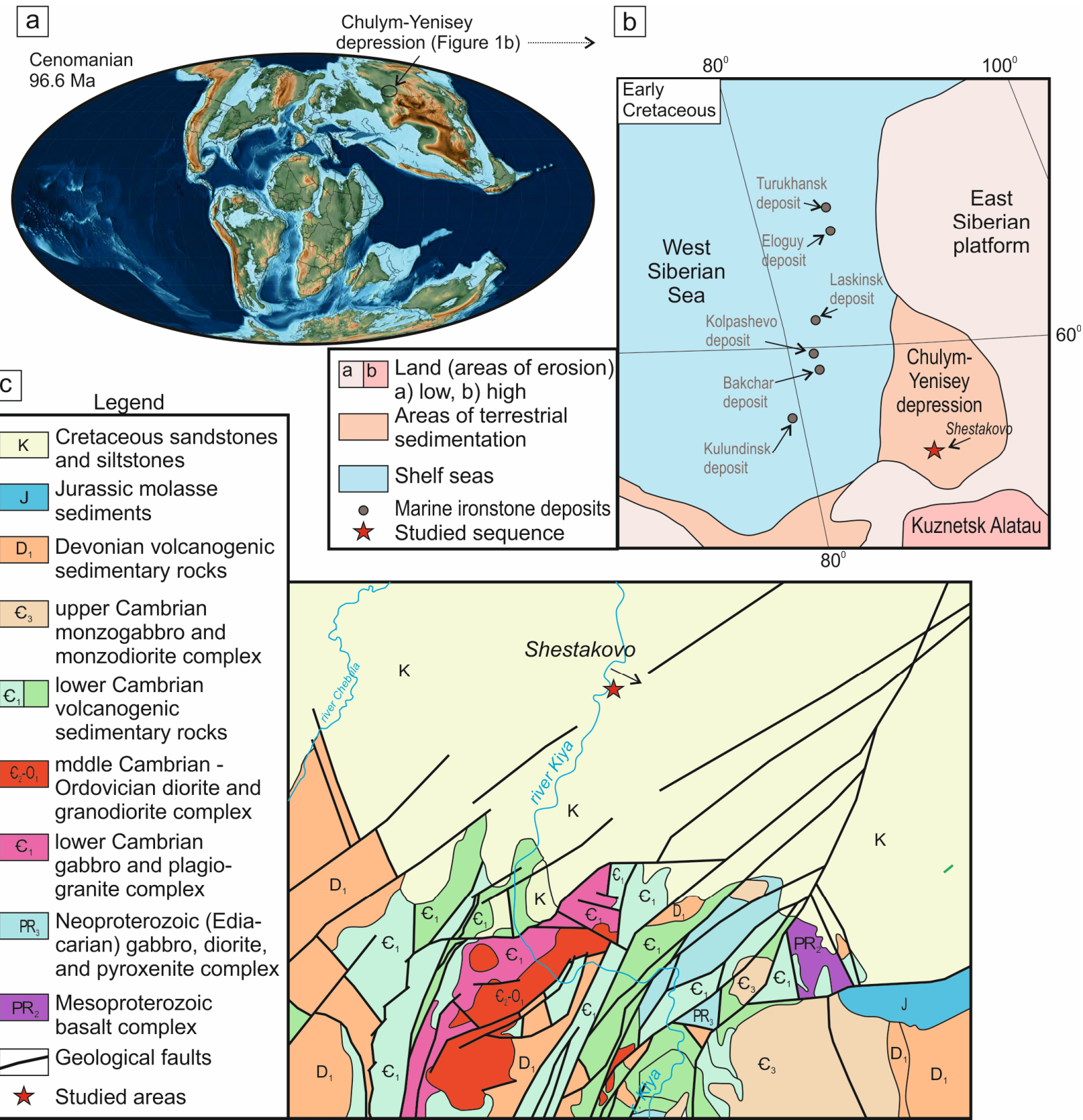

Figure 1. (a) Global Cenomanian plate reconstruction with the location of the West Siberian Sea [38]. (b) Early Cretaceous paleogeographic map of the region studied between the West Siberian Sea and Altai-Sayan [36]. (c) Simplified geological map of the studied Chulym-Yenisey basin and north-western part of Altai-Sayan region [52].

The Late Jurassic and Early Cretaceous of the Chulym-Enisey basin witnessed reduced tectonic activity, the formation of a peneplain, and the development of deep chemically weathered crusts, including the formation of an iron duricrust. Sedimentation within the Chulym-Yenisey took place in a continental setting. Variegated fine-grained sediments of the Ilek Formation were deposited during the Early Cretaceous. The deposition of the Kiya Formation took place in the Albian-Cenomanian period after the tectonic uplift of the region. Cretaceous sediments of Ilek and Kiya Formations contain a variety of continental fossils, including the following remains: Psittacosaurus sibiricus, Evgenavis nobilis, Hemicorbicula elegans, Musculiopsis dolosus, Darwinula contracta, Cypridea faveolata, Ginkgo digitata, Cladophlebis longifotia, Sequoia reichehbachii, Sphaerium tasaranica, etc. [34,53-56]. The interval from the Cenomanian to the Eocene witnessed a period of tectonic dormancy, during which the peneplanation took place. 


\section{Materials and Methods}

Twenty-five samples were collected from the Shestakovo outcrop $\left(55^{\circ} 54^{\prime} 26^{\prime \prime} \mathrm{N}\right.$; $87^{\circ} 57^{\prime} 13^{\prime \prime}$ E), Kemerovo Province, Western Siberia, Russia (Figure 1C). For the petrographic investigation of the samples under the optical light microscope, polished thin sections were prepared using standard methods. The bulk mineralogical composition of the samples was determined by a Rigaku Ultima IV (Rigaku, Tokyo, Japan) X-ray diffractometer (XRD) equipped with a $\mathrm{Cu}-\mathrm{K} \alpha$ radiation source and operated at a current of $30 \mathrm{~mA}$ and a voltage of $40 \mathrm{kV}$. The finely powdered samples were examined from $3-65^{\circ} 2 \theta$ using a step of $0.02^{\circ}$ at a scanning rate of $1 \mathrm{~s}$ per step. Electron microscopic investigations were carried out on carbon-coated $(15 \mathrm{~nm})$, polished thin sections using a TESCAN VEGA 3 SBU (Tescan Orsay Holding, Brno, Czech Republic) scanning electron microscope (SEM) equipped with an OXFORD X-Max 50 (OXFORD instruments, Abingdon, UK) energy dispersive spectroscopy (EDS). The accelerating voltage for the SEM study was set to $20 \mathrm{kV}$, with a probe current intensity varying between 3.5 and $12.2 \mathrm{nA}$. The chemical composition of different minerals was determined by repeated measurements of more than 10 points per mineral by SEM-EDS. The transmission electron microscopy (TEM) study was carried out on ten samples using a JEOL JEM-2100F (JEOL Ltd., Tokyo, Japan) instrument. A drop of a fine particle suspension was transferred to a copper grid ( 300 mesh, $3.05 \mathrm{~mm}$ in diameter) covered with a carbon film before TEM investigation at $200 \mathrm{kV}$.

Major element concentrations of the powdered samples (20 samples) were determined by a HORIBA XGT 7200 (Horiba, Kyoto, Japan) X-ray fluorescence (XRF) microscope operated at a tube current of $1 \mathrm{~mA}$, beam diameter of $1.2 \mathrm{~mm}$, and a voltage of $50 \mathrm{kV}$. Pressed and fused pellets were prepared for XRF analysis. The average value was calculated from five analytical points evenly distributed on the pellet surface for each sample. Loss on ignition (L.O.I.) was obtained by heating sample powders to $900{ }^{\circ} \mathrm{C}$ for $9 \mathrm{~h}$. The detection limit for major elements was better than $0.01 \mathrm{wt}$. \%. Concentrations of trace elements (TEs), including rare earth elements (REEs), were measured on 20 samples using inductively coupled plasma-mass spectroscopy (ICP-MS), conducted on a NexION 300D (PerkinElmer Inc., Waltham, MA, United States) instrument. About $0.5 \mathrm{~g}$ of the powdered sample was fused at $1050{ }^{\circ} \mathrm{C}$ for about 15 min using a mixture of $\mathrm{LiBO}_{2} / \mathrm{Li}_{2} \mathrm{~B}_{4} \mathrm{O}_{7}(0.8 \mathrm{~g})$ as the fluent agent. The glass beads were dissolved in a mixture of 5:4:1.5 $\mathrm{HF}, \mathrm{HNO}_{3}$ and $\mathrm{HClO}_{4}$ solutions at $120^{\circ} \mathrm{C}$ in a platinum crucible for $6 \mathrm{~h}$. The liquid extract was allowed to evaporate at $160{ }^{\circ} \mathrm{C}$. Afterwards, the sample residue was dissolved in $10 \mathrm{~mL}$ of $5 \mathrm{M} \mathrm{HNO}_{3}$ solution, filtered, and analyzed for the REEs concentrations.

Elemental concentrations were normalized to $\mathrm{Al}$ content to remove the effect of variable terrigenous input $[57,58] . \mathrm{Ce}^{*}, \mathrm{Eu}^{*}, \mathrm{Y}_{\mathrm{sn}} / \mathrm{Ho}_{\mathrm{sn}}$ are the theoretical $\mathrm{Eu}, \mathrm{Ce}, \mathrm{Y}$ and Ho values derived from a post-Archean Australian shale (PAAS) normalized rare earth element (REE) pattern. The enrichment factor (EF) was calculated for each sample using the standard formula [58]. The $\mathrm{Al} \mathrm{EF}$ was calculated as follows: $\mathrm{Al} \mathrm{EF}=\mathrm{Al}_{\text {sample }} / \mathrm{Al}_{\text {PAAS }}$. The Chemical Index of Alteration (CIA) was calculated according to the relation $100 \times$ $\left(\mathrm{Al}_{2} \mathrm{O}_{3} /\left(\mathrm{Al}_{2} \mathrm{O}_{3}+\mathrm{CaO}+\mathrm{Na}_{2} \mathrm{O}+\mathrm{K}_{2} \mathrm{O}\right)\right)[59,60]$.

The stable carbon and oxygen isotope ratios were obtained on seven carbonate-bearing rock samples of the studied area. Powdered samples were reacted with phosphoric acid at $70{ }^{\circ} \mathrm{C}$ using a Gasbench II connected to a Thermo Finnigan Five Plus mass spectrometer (Thermo Fisher Scientific, Waltham, MA, United States) [61]. Carbon and oxygen isotope values are reported per mil relative to V-PDB (NBS19 and LSVEC, respectively). Reproducibility was checked by replicate analysis of laboratory standards and was $\pm 0.07 \%$ o $(1 \sigma)$ for both carbon and oxygen isotope analyses.

\section{Results}

\subsection{Lithology and Mineralogy}

Iron-bearing sedimentary rocks occur as thin bands within the Lower Cretaceous Ilek and Upper Cretaceous Kiya Formations in the Chulym-Enisey depression (Figure 2). The Ilek Formation consists of greenish-gray sandstones, brick-red or bluish-gray sandy 
siltstones, silty ironstones, and bluish-gray claystones. The thickness of the Ilek Formation ranges up to 10-18 $\mathrm{m}$ within the studied area, increasing in the north-western corner of the Chulym-Enisey depression. The fine-grained ironstone shows reddish or brick color, and it consists mainly of iron-rich chlorite, calcite, siderite, and terrigenous silty components (Figure 3A,B). Sandstone is brownish or greenish-gray with rare cross-bedding (Figure 3C). Siltstones are brick-red or bluish-gray. They consist of carbonate, often forming nodules, with calcareous and chloritic matrix (Figure 3E). Siltstone layers consist of an admixture of sand, as well as cm-scale fragments of lignite. The thickness of sandstones and siltstones in the Ilek Formation varies from 1.8 to $11 \mathrm{~m}$ and from 0.2 to $1.5 \mathrm{~m}$, respectively. The thickness of iron-bearing siltstones and ironstones varies from 0.3 to $1 \mathrm{~m}$.

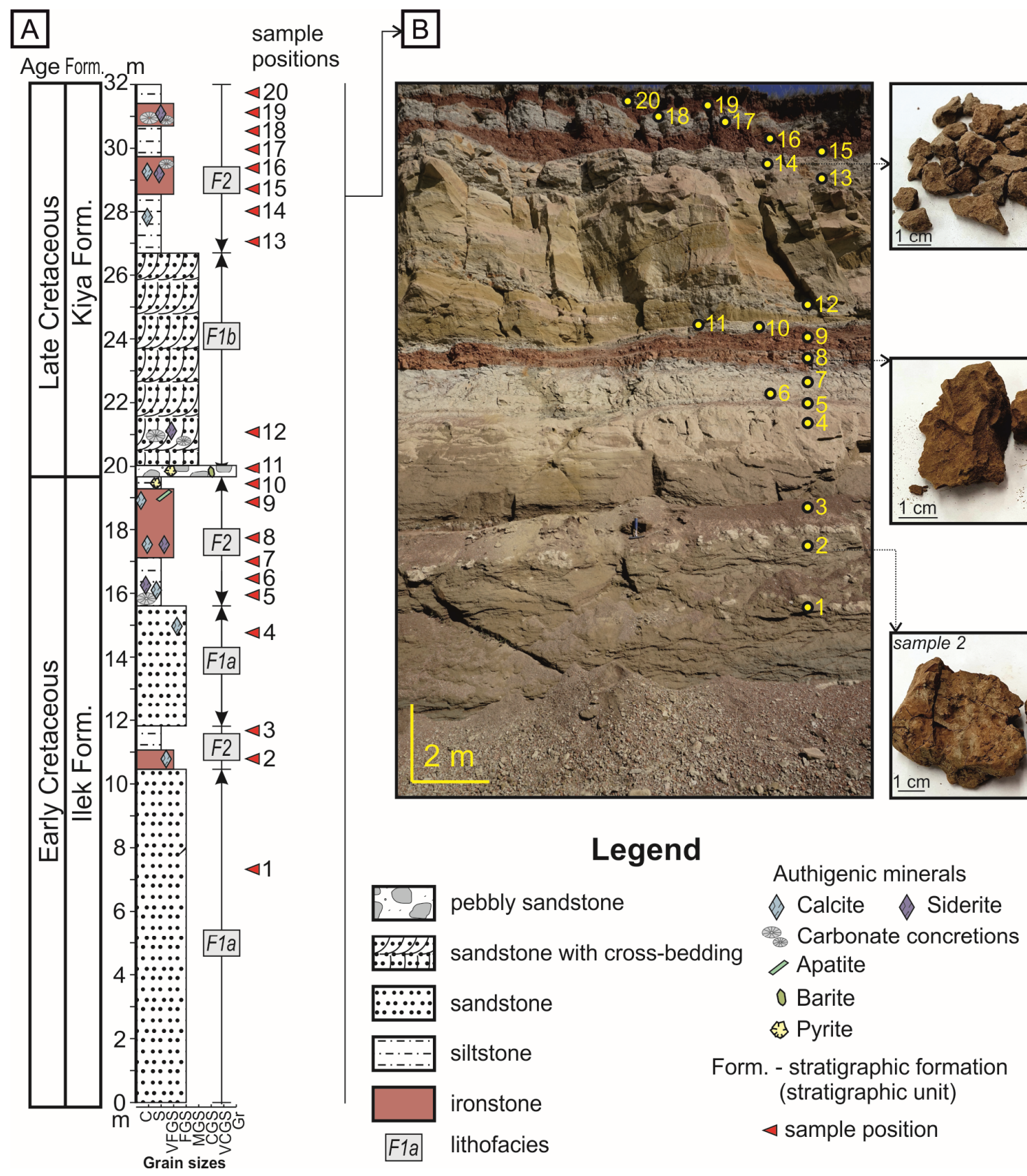

Figure 2. (A) Lithostratigraphy of the studied Cretaceous deposits, and (B) field photograph showing the vertical section of the deposit, sample positions and close-up view of samples (grain sizes: C—clay; S-silt; VFGS-very fine-grained sand; FGS—fine-grained sandstone; MGS—-medium-grained sandstone; CGS—coarse-grained sandstone; VCGS—very coarse-grained sandstone; $\mathrm{Gr}$-gravel). 

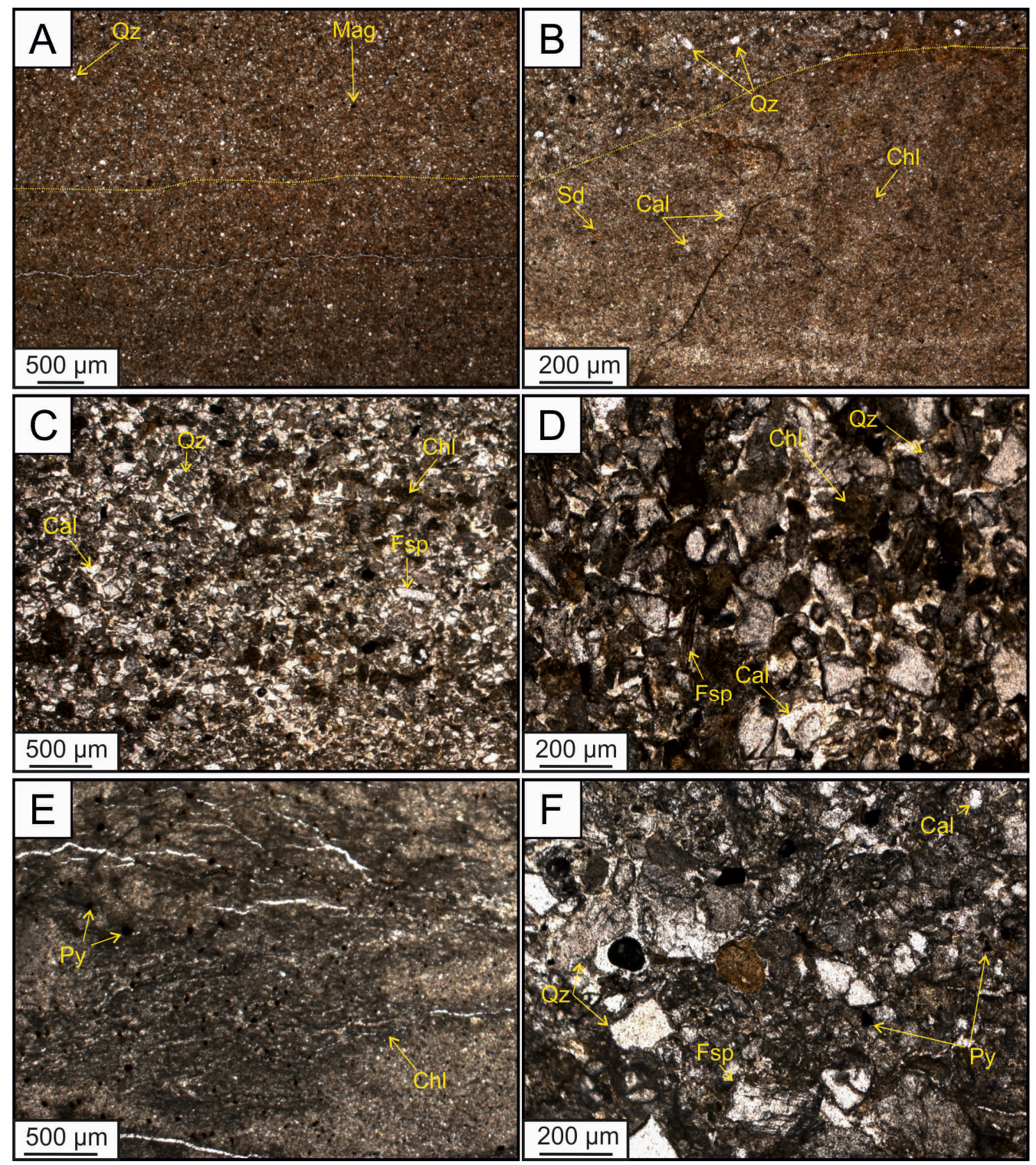

Figure 3. Photomicrographs showing the main lithotypes: (A,B) Silty ironstone consisting of ironrich chlorite matrix and siderite-calcite cement, showing thin lamination (boundaries marked by the dotted yellow line). (C,D) Sandstone with quartz, feldspar, chlorite matrix, and rare calcite crystals. (E) Siltstone with pyrite, calcite cement, and illite-chlorite matrix. (F) Matrix of gritstone containing quartz, feldspar, calcite, and pyrite. Cal—calcite; Chl—chlorite group (possibly chamosite); Fsp—feldspar; Ilm—ilmenite; Mag—magnetite; Py—pyrite; Sd—siderite; Qz-quartz.

The Kiya Formation includes cross-bedded sandstones with intervening gray siltstones, gray clays, lignite lenses, ironstones, and gritstones. The thickness of this Formation varies from 10 to $40 \mathrm{~m}$ within the study area. Ironstones are characterised by lenticular geometry, brown color, finely laminated structure, consisting mainly of siderite. Sandstone is cross-bedded, gray to greenish-gray or brownish-gray, and medium-grained (Figure 3D) with a kaolinite-nontronite matrix. Siderite and claystone nodules are common features within the sandstone. Siltstones and clays are gray, greenish-gray, and yellowish-gray with parallel lamination. Siltstones consist of quartz, feldspars, kaolinite, and illite with siderite micro-concretions. A thin layer of gritstone (up to $0.5 \mathrm{~m}$ thick) occurs at the base of the Kiya Formation. It contains rounded and sub-angular fragments up to 3-8 mm diameter and carbonate (calcite) cement (Figure 3F). The thickness of sandstones and siltstones in the 
Kiya Formation vary 4-14 m and 0.5-6 m, respectively. Ironstones layers have a thickness ranging from 0.5 to $1.5 \mathrm{~m}$.

Distinctive lithofacies characterize the Cretaceous deposits of the Chulym-Yenisey basin. The Kiya river basin shows two main lithofacies of litho-feldspatho-quartzose sandstone (F1) and siltstone (F2). The medium- to fine-grained sandstone is cross-stratified (F1b). Pebbly sandstone may occur at the bottom of medium-grained sandstone. The fine-grained sandstone (F1a) is overlain by siltstone. The siltstone beds incorporate reddishbrown ironstone and are calcareous in places. The fining-upward grain size variation from medium- to fine-grained sandstone, alteration with siltstone, occasional pebbly base, and the nature of cross-stratifications indicate the fluvial channel origin of the Kiya Formation (see also $[20,21])$. The siltstones alternating within the sandstones with thin layers of ironstones and lenses of lignite show floodplain-lacustrine-boggy facies.

The framework of the sandstone consists of quartz $(50 \%)$, feldspar $(37 \%)$, and rock fragments (13\%). Heavy minerals include zircon, rutile, monazite, ilmenite, magnetite, hematite, and silver. Diagenetic constituents include calcite, siderite, dolomite, goethite, dolomite, apatite, barite, and pyrite. Clay minerals are chlorite group (possible chamosite), nontronite, kaolinite, illite, and beidellite. Mineral composition of ironstones (lithofacies F2) varies widely as follows (according to quantitative XRD analysis): quartz 29.8-57.6\%, feldspar $13.8-31.7 \%$, siderite $8.0-12.1 \%$, calcite $15.3-35.4 \%$, chlorite group $6.5-7.5 \%$, nontronite 1.1-13.3\%, and other minerals (goethite, kaolinite, illite, apatite, dolomite, etc.) up to $5 \%$ (Figure 4). The ironstone in the Ilek Formation contains more chlorite (chamosite) and calcite and less siderite and nontronite than the Kiya Formation (Figure 4).

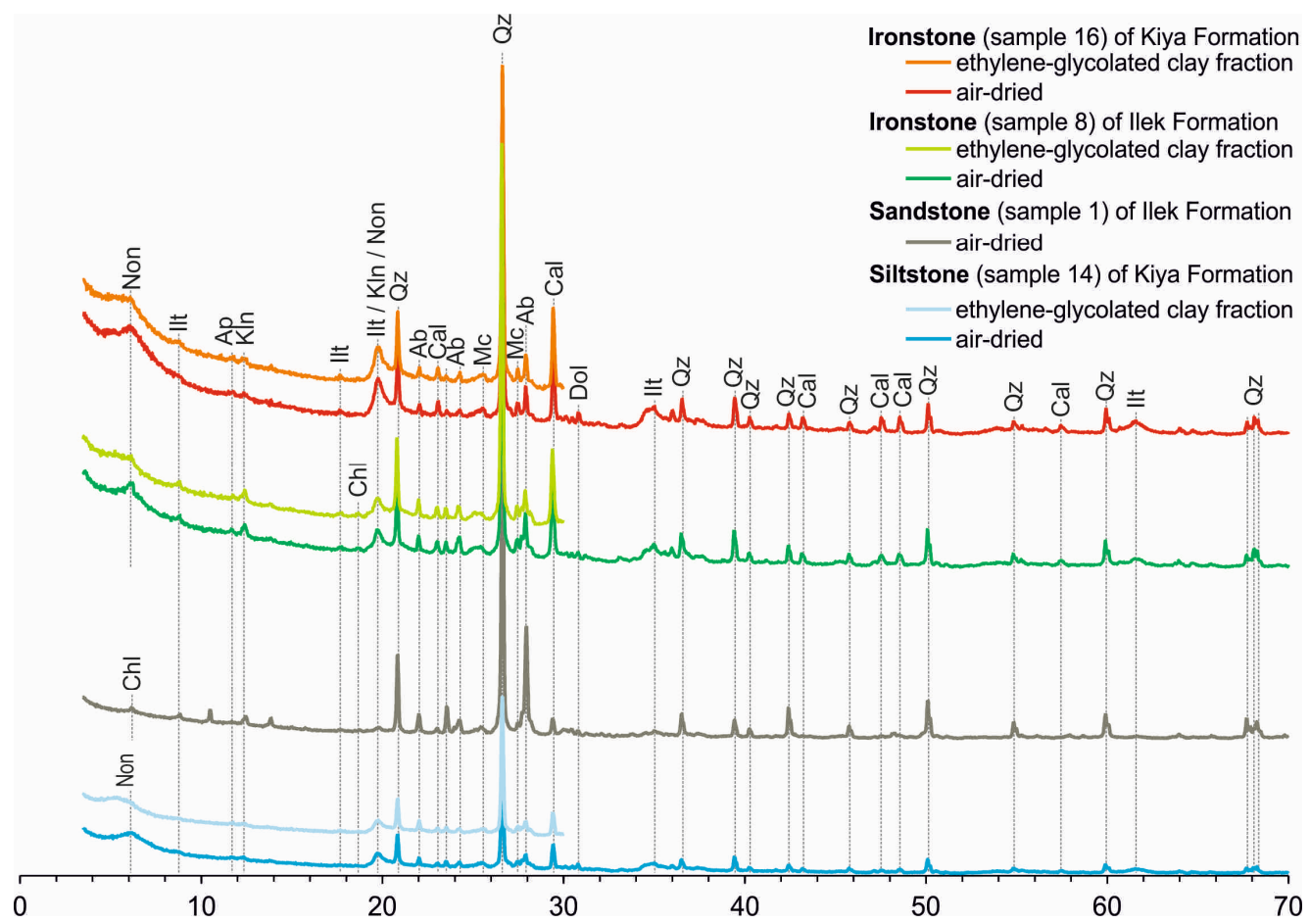

Figure 4. XRD patterns of representative samples of the ironstones and clastic rocks from Ilek and Kiya Formations. Ab-albite; Ap—hydroxylapatite; Cal—calcite, Chl—chlorite group (possible chamosite); Dol—dolomite; Ilt—illite; Kln—kaolinite; Mc—microcline; Non—nontronite; Qz—quartz.

Grains of quartz and feldspars are angular and sub-rounded. Besides quartz and feldspar, carbonates are frequent in the powdered samples. Carbonate includes a mixture of calcite, aragonite, and siderite (Figures $5 \mathrm{a}-\mathrm{c}, \mathrm{h}$ and 6 ). 


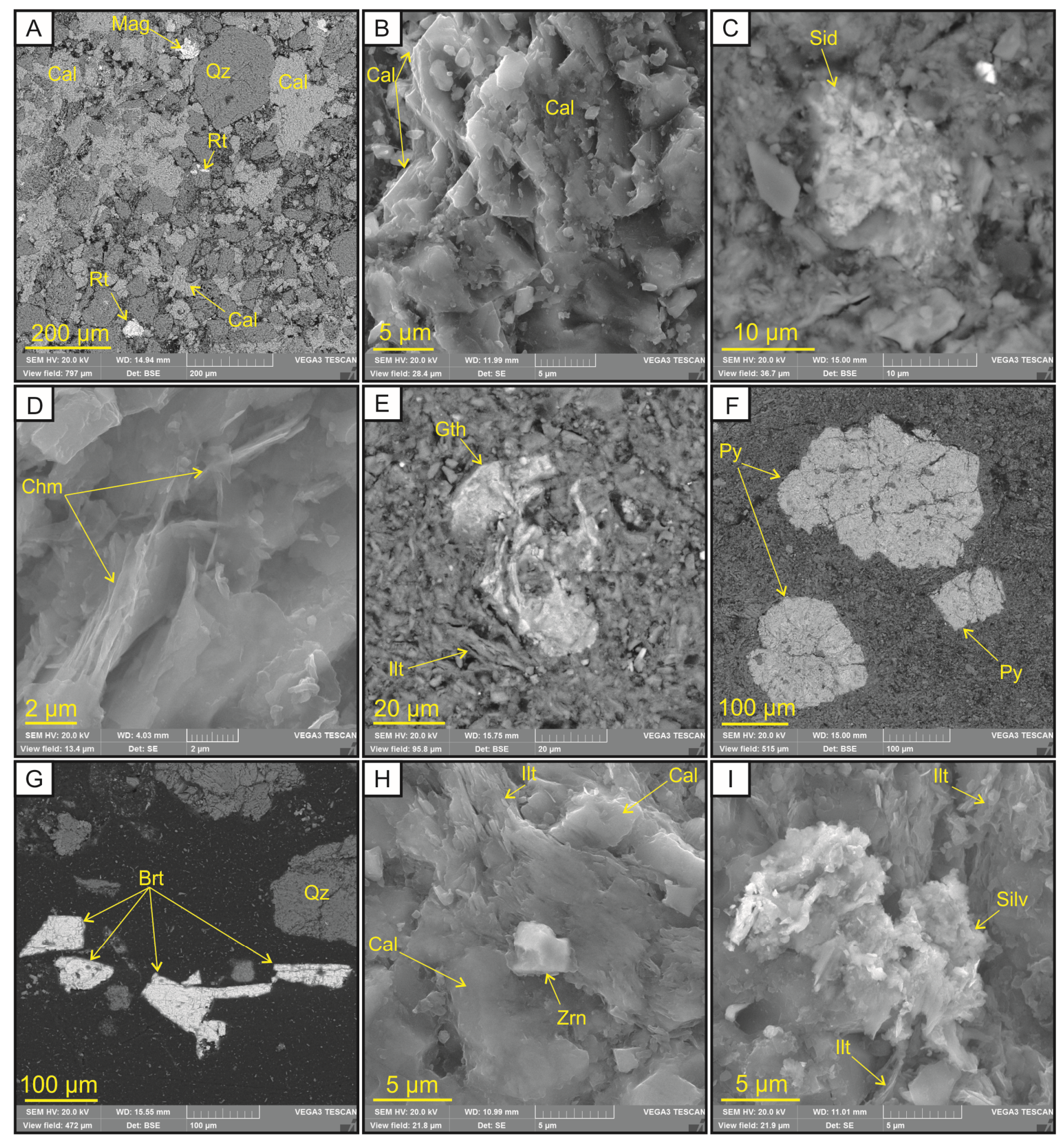

Figure 5. SEM images showing (A,B) calcite cement in carbonate concretion within siltstone of Ilek Formation. (C) Siderite crystal in illite-nontronite matrix of the ironstone of the Kiya Formation. (D) Flakey structure of the chamosite. (E) Goethite aggregate in the illite matrix of the ironstone. (F) Pyrite grains in the siltstone. (G) Barite crystals in the gritstone. (H) Zircon within the siltstone of Kiya Formation. (I) Silver in illite matrix of the sandstone of Ilek Formation. Brt—barite; Cal—calcite; Chm—chamosite; Gth—goethite; Ilt—illite; Mag—magnetite; Py—pyrite; Sid—siderite; Silv—silver; Qz-quartz; Rt—rutile; Zrn—zircon. The images are (A,C,E,F,G) backscattered electron (BSE) and (B,D,H,I) secondary electron (SE) micrographs. 


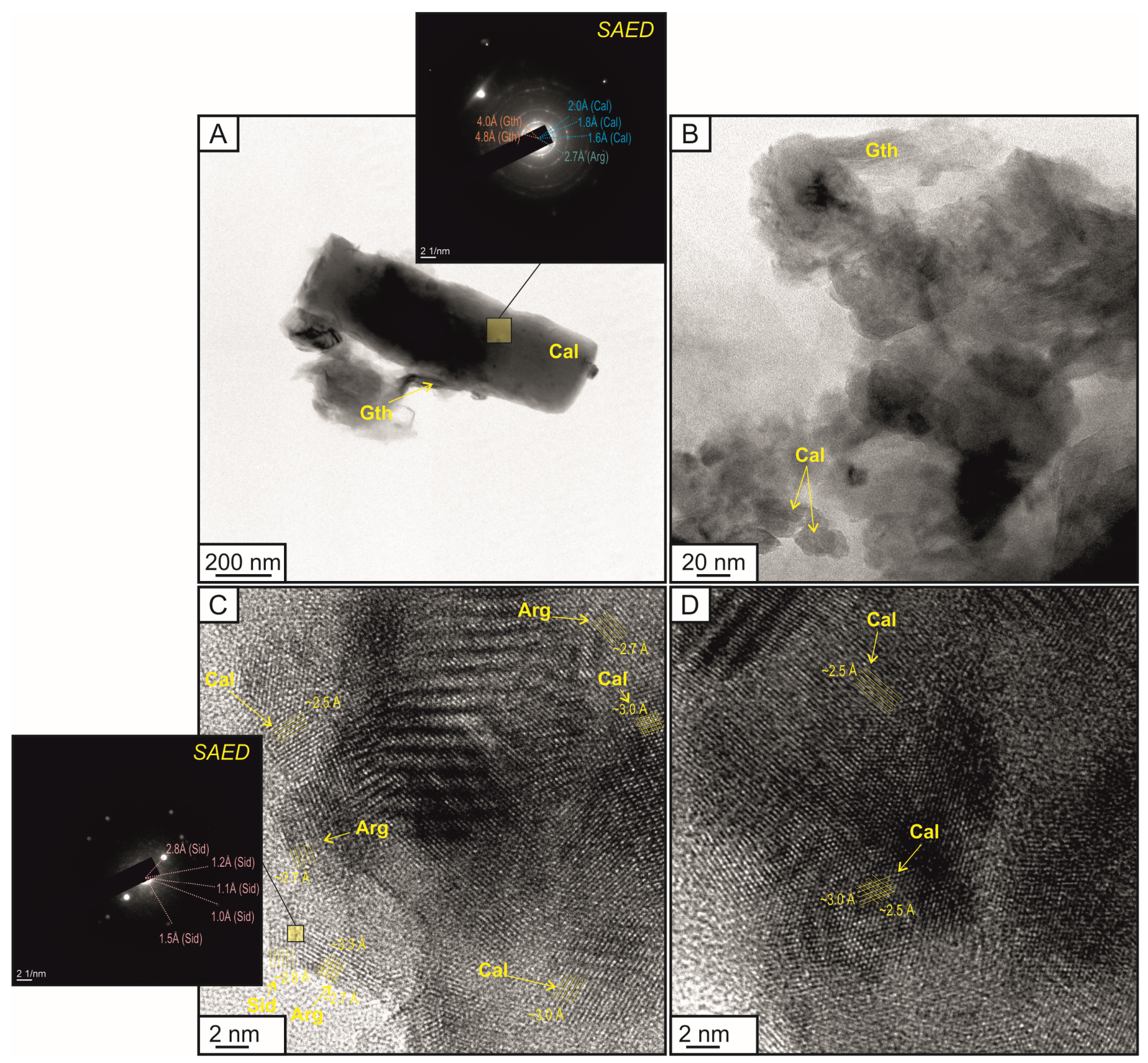

Figure 6. Transmission electron microscopy (TEM) images with selected area electron diffraction (SAED) patterns showing calcite (Cal), aragonite (Arg), siderite (Sid), and goethite (Gth) within the iron-rich cement and grains of Cretaceous Ilek and Kiya Formations. (A,B) Low-resolution TEM images showing carbonate and goethite crystals. The SAED pattern with main reflections is used for mineral identification. (C,D) High-resolution TEM images showing short isometric carbonate

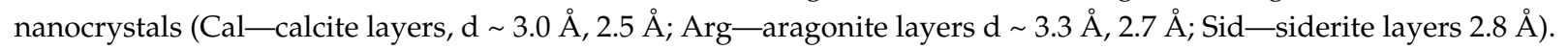

Calcite and aragonite are characterized by the following compositional variations: 64.4-94.5 mol.\% $\mathrm{CaCO}_{3}$, up to $3.2 \mathrm{~mol} . \% \mathrm{MgCO}_{3}$, up to $3.1 \mathrm{~mol}$ \% $\mathrm{FeCO}_{3}$, up to $1.4 \mathrm{~mol} \%$ $\mathrm{MnCO}_{3}$. Siderite occurs as nodules up to $20 \mathrm{~cm}$ in diameter or as individual crystals with an average length of 10-50 $\mu \mathrm{m}$ (Figure 5C) in all lithotypes of the sequence. The chemical composition of siderite is 75.0-89.7 mol.\% $\mathrm{FeCO}_{3}, 1.8-9.4 \mathrm{~mol}$ \% $\mathrm{MgCO}_{3}, 0.7-1.6 \mathrm{~mol}$ \% $\mathrm{CaCO}_{3}, 0.7-1.4 \mathrm{~mol} \% \mathrm{MnCO}_{3}$. The crystal size varies from 4 to $18 \mu \mathrm{m}$. TEM images (Figure 6) show distinctive interplanar spacings for the following minerals: calcite of $3.0 \AA$, $2.5 \AA, 2.1 \AA$; aragonite of $2.7 \AA$; siderite of $2.8 \AA, 1.5 \AA$. Chamosite forms clumps with flakey structure (Figure 5D) in the matrix of ironstones and terrigenous rocks. Goethite is less 
common among authigenic minerals and forms micro-clusters up to $40 \mu \mathrm{m}$ in diameter (Figure 5E) or thin crusts (Figure 6). Pyrite occurs mainly in bluish-gray siltstones of both Ilek and Kiya Formations as sub-isometric aggregates (Figure 5F) ranging in length from 25 to $2000 \mu \mathrm{m}$ similar to "sunflowers" with elongated cores. Barite occurs in the gritstone matrix as aggregates up to $120-\mu \mathrm{m}$ long. They occur within the gritstone matrix (Figure 5G). Native silver crystals are recorded in the form of irregular grains in the illite matrix of brownish-gray sandstones of the Ilek Formation (Figure 5I).

\subsection{Geochemistry}

The iron-bearing rocks, including ironstones of the Ilek and Kiya Formations, have $\mathrm{Fe}_{2} \mathrm{O}_{3 \text { (total) }}$ content varying from $8.6 \%$ to $18.9 \%$ and from $8.5 \%$ to $16.4 \%$, respectively (Table 1). The bulk chemical composition of sandstones is characterised by the $\mathrm{Fe}_{2} \mathrm{O}_{3 \text { (total) }}$ below $5.2 \%$, with $\mathrm{SiO}_{2} 49.0-67.0 \%$ and $\mathrm{Al}_{2} \mathrm{O}_{3} 10.8-13.7 \%$. Carbonate cemented gritstones display an increased $\mathrm{CaO}$ content up to $13.6 \%$. Calcite nodules up to $20 \mathrm{~cm}$ in diameter have the following average composition: $\mathrm{CaO} 23.6 \%, \mathrm{SiO}_{2} 36.3 \%, \mathrm{Al}_{2} \mathrm{O}_{3} 8.6 \%, \mathrm{Fe}_{2} \mathrm{O}_{3 \text { (total) }} 3.0 \%$.

Table 1. XRF data of major oxides (wt. \%) obtained for the analyzed samples of the studied rocks.

\begin{tabular}{ccccccccccccc}
\hline Form. & Rock & Sample & $\mathbf{N a}_{2} \mathbf{O}$ & $\mathbf{M g O}$ & $\mathbf{A l}_{2} \mathbf{O}_{3}$ & $\mathbf{S i O}_{2}$ & $\mathbf{K}_{2} \mathbf{O}$ & $\mathbf{C a O}$ & $\mathbf{T i O}_{2}$ & $\mathbf{M n O}_{2} \mathbf{F e}_{2} \mathbf{O}_{3} \mathbf{t}$ & $\mathbf{L O I}$ \\
\hline Kiya & silt. & 20 & 1.1 & 1.0 & 15.1 & 60.3 & 2.3 & 0.8 & 0.7 & 0.4 & 8.5 & 9.9 \\
\hline Kiya & iron. & 16 & 0.7 & 0.6 & 13.1 & 56.8 & 2.0 & 0.8 & 0.7 & 0.6 & 16.4 & 8.1 \\
\hline Kiya & ir.-b. silt. & 14 & 1.2 & 0.9 & 15.1 & 60.9 & 2.4 & 0.8 & 0.7 & 0.5 & 10.9 & 6.6 \\
\hline Ilek & sand. & 12 & 2.0 & 1.0 & 11.8 & 67.0 & 1.7 & 3.1 & 0.4 & 0.0 & 3.2 & 9.5 \\
\hline Ilek & grit. & 11 & 1.0 & 1.2 & 10.8 & 59.3 & 1.6 & 13.6 & 0.7 & 0.1 & 2.6 & 9.1 \\
\hline Ilek & silt. & 10 & 0.6 & 3.4 & 15.5 & 58.8 & 2.0 & 3.8 & 0.9 & 0.1 & 7.0 & 7.8 \\
\hline Ilek & iron. & 9 & 0.5 & 2.6 & 14.6 & 49.0 & 2.0 & 6.1 & 0.8 & 0.1 & 18.2 & 5.9 \\
\hline Ilek & iron. & 8 & 0.6 & 3.0 & 14.5 & 52.0 & 1.9 & 6.9 & 0.8 & 0.1 & 18.9 & 1.3 \\
\hline Ilek & silt. & 7 & 1.6 & 2.5 & 14.7 & 59.4 & 1.8 & 5.2 & 0.8 & 0.1 & 4.1 & 9.8 \\
\hline Ilek & silt. & 6 & 1.5 & 2.7 & 14.7 & 61.9 & 1.8 & 5.0 & 0.8 & 0.1 & 4.2 & 7.3 \\
\hline Ilek & calc. & 5 & 0.7 & 1.3 & 8.6 & 36.3 & 1.3 & 23.6 & 0.4 & 0.1 & 3.0 & 24.5 \\
\hline Ilek & sand. & 4 & 1.8 & 2.1 & 13.7 & 56.7 & 1.6 & 5.2 & 0.8 & 0.1 & 4.8 & 13.2 \\
\hline Ilek & silt. & 3 & 1.2 & 2.6 & 14.5 & 55.1 & 2.0 & 5.6 & 0.8 & 0.1 & 5.1 & 12.8 \\
\hline Ilek & ir.-b. silt. & 2 & 0.5 & 2.8 & 14.5 & 51.8 & 2.2 & 9.7 & 0.8 & 0.2 & 8.6 & 8.9 \\
\hline Ilek & sand. & 1 & 1.3 & 2.1 & 13.3 & 60.7 & 1.5 & 4.6 & 0.8 & 0.1 & 5.2 & 10.4 \\
\hline
\end{tabular}

Note: Form.—stratigraphic formation; silt.—siltstone; iron.—ironstone; ir.-b. silt.—iron-bearing siltstone; sand.—sandstone; grit.—gritstone; calc.-calcareous concretion.

Trace element concentrations are presented in Figure 7 and Table 2. The studied rocks display high contents of Ba (241-6377 ppm), As (2.6-327.5 ppm), Zn (31.2-94.7 ppm), Co (9.7-33.3 ppm), Ag (0.1-0.3 ppm), Sb (0.6-5.6 ppm), and Cd (0.2-0.8 ppm). Average concentrations of $\mathrm{Cr}, \mathrm{Ni}, \mathrm{Cu}, \mathrm{Ga}, \mathrm{Ge}, \mathrm{Sr}, \mathrm{Zr}, \mathrm{Nb}, \mathrm{Sn}, \mathrm{Cs}, \mathrm{Hf}, \mathrm{Ta}, \mathrm{W}, \mathrm{Pb}, \mathrm{Bi}$, Th, and $\mathrm{U}$ are lower than that of the bulk continental crust [62]. 


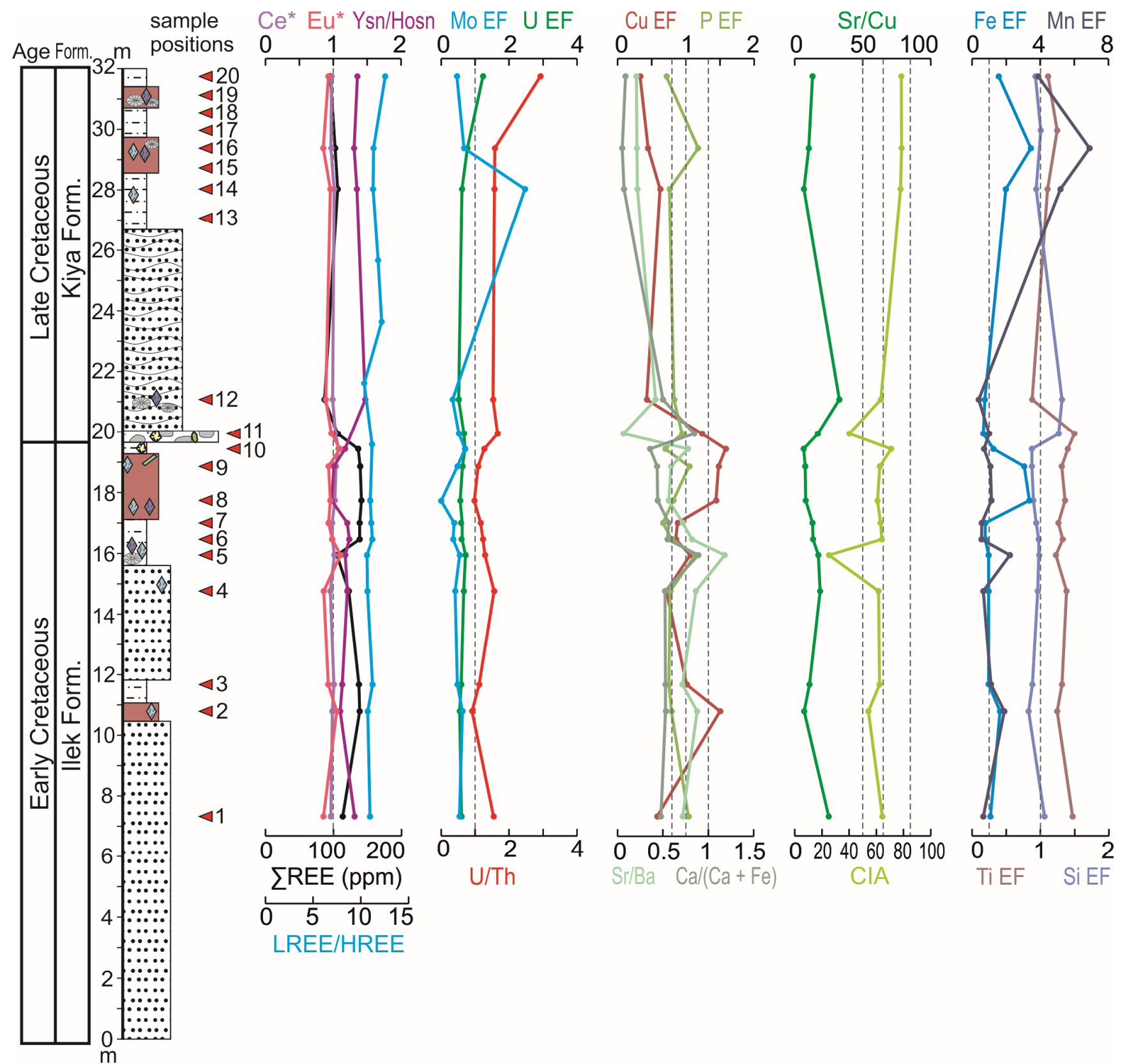

Figure 7. Lithostratigraphic column and related geochemical distribution profiles of rare earth elements (REE), light rare earth elements/heavy rare earth elements (LREE/HREE), $\mathrm{Ce}^{*}, \mathrm{Eu}^{*}$ and $\mathrm{Y}_{\mathrm{sn}} / \mathrm{Ho}_{\mathrm{sn}}$, elemental enrichment factors (EFs), and geochemical proxies of $\mathrm{U} / \mathrm{Th}, \mathrm{Sr} / \mathrm{Ba}, \mathrm{Sr} / \mathrm{Ce}, \mathrm{CIA}$.

Table 2. ICP-MS data of some trace elements (ppm) analyzed for the studied samples of rocks.

\begin{tabular}{|c|c|c|c|c|c|c|c|c|c|c|c|c|c|c|c|}
\hline Form. & Rock & Sample & Co & $\mathrm{Ni}$ & $\mathrm{Cu}$ & $\mathrm{Zn}$ & $\mathrm{Sr}$ & $\mathrm{Zr}$ & Mo & Ag & $\mathbf{B a}$ & $\mathbf{P b}$ & $\mathbf{B i}$ & Th & $\mathrm{U}$ \\
\hline Kiya & silt. & 20 & 10.6 & 15.8 & 9.0 & 45.7 & 116.5 & 71.5 & 0.5 & 0.19 & 567.9 & 12.7 & 0.08 & 4.3 & 3.3 \\
\hline Kiya & iron. & 16 & 10.0 & bdl & 10.5 & 51.8 & 106.2 & 73.7 & 0.6 & 0.12 & 499.7 & 8.5 & 0.07 & 4.3 & 1.8 \\
\hline Kiya & ir.-b. silt. & 14 & 11.1 & 7.9 & 17.1 & 46.8 & 112.1 & 73.0 & 2.7 & 0.08 & 516.0 & 11.6 & 0.04 & 4.0 & 1.6 \\
\hline Ilek & sand. & 12 & 9.7 & 5.1 & 9.2 & 31.2 & 299.3 & 68.8 & 0.3 & 0.13 & 718.0 & 7.6 & 0.03 & 2.7 & 1.1 \\
\hline Ilek & grit. & 11 & 12.7 & 9.8 & 24.3 & 34.6 & 407.5 & 64.3 & 0.4 & 0.22 & 6377.5 & 9.8 & 0.07 & 3.0 & 1.3 \\
\hline Ilek & silt. & 10 & 33.3 & 27.1 & 44.6 & 94.7 & 290.3 & 137.3 & 0.8 & 0.22 & 374.2 & 16.4 & 0.17 & 5.9 & 1.9 \\
\hline Ilek & iron. & 9 & 20.4 & 22.9 & 39.1 & 72.3 & 292.6 & 137.8 & 0.5 & 0.30 & 498.2 & 14.1 & 0.14 & 5.7 & 1.6 \\
\hline Ilek & iron. & 8 & 17.3 & 23.5 & 37.9 & 68.4 & 298.8 & 138.0 & bdl & 0.28 & 530.7 & 12.9 & 0.12 & 5.7 & 1.4 \\
\hline
\end{tabular}


Table 2. Cont

\begin{tabular}{ccccccccccccccccc}
\hline Form. & Rock & Sample & $\mathbf{C o}$ & $\mathbf{N i}$ & $\mathbf{C u}$ & $\mathbf{Z n}$ & $\mathbf{S r}$ & $\mathbf{Z r}$ & $\mathbf{M o}$ & $\mathbf{A g}$ & $\mathbf{B a}$ & $\mathbf{P b}$ & $\mathbf{B i}$ & $\mathbf{T h}$ & $\mathbf{U}$ \\
\hline Ilek & silt. & 7 & 14.0 & 4.8 & 23.4 & 59.7 & 302.6 & 134.2 & 0.4 & 0.20 & 421.4 & 10.1 & 0.10 & 5.0 & 1.5 \\
\hline Ilek & silt. & 6 & 13.4 & 4.0 & 22.8 & 58.0 & 303.1 & 132.8 & 0.4 & 0.18 & 369.9 & 9.8 & 0.09 & 4.9 & 1.5 \\
\hline Ilek & calc. & 5 & 17.1 & 1.0 & 16.6 & 36.8 & 284.3 & 77.3 & 0.3 & 0.18 & 241.0 & 7.7 & 0.08 & 3.3 & 1.1 \\
\hline Ilek & sand. & 4 & 11.8 & 14.3 & 17.7 & 54.2 & 327.0 & 102.8 & 0.4 & 0.16 & 380.0 & 9.4 & 0.09 & 4.0 & 1.6 \\
\hline Ilek & silt. & 3 & 16.8 & 19.0 & 26.6 & 63.7 & 286.5 & 130.9 & 0.5 & 0.20 & 401.8 & 11.8 & 0.10 & 5.2 & 1.5 \\
\hline Ilek & ir.-b. silt. & 2 & 19.3 & 19.8 & 39.5 & 85.8 & 265.2 & 125.5 & 0.6 & 0.19 & 303.1 & 13.8 & 0.12 & 5.9 & 1.4 \\
\hline Ilek & sand. & 1 & 13.6 & 16.9 & 13.9 & 46.7 & 346.3 & 93.8 & 0.5 & 0.25 & 482.8 & 9.9 & 0.07 & 3.5 & 1.4 \\
\hline
\end{tabular}

Note: bdl-below detection limit; Form.—stratigraphic formation; silt.—siltstone; iron.—ironstone; ir.-b. silt.-iron-bearing siltstone; sand.-sandstone; grit.-gritstone; calc.-calcareous concretion.

The total contents of rare earth elements and yttrium (REY; Table 3) are higher in ironstones (up to $141 \mathrm{ppm}$ ) and terrigenous rocks of the Ilek Formation than in the rest of the succession (Figure 7, Table 4). A weak positive $\mathrm{Eu}^{*}$ is noted in the siltstones with carbonates of the Ilek Formation. Ce* shows robust average values 1.0. The HREE content increases relative to light LREE in rocks containing carbonates.

Table 3. ICP-MS data of rare earth elements and yttrium (ppm) analyzes for the studied samples.

\begin{tabular}{cccccccccccccccccccc}
\hline Form. & Rock & Sample & La & Ce & Pr & Nd & Sm & Eu & Gd & Tb & Dy & Ho & Er & Tm & Yb & Lu & Y & REY \\
\hline Kiya & silt. & 20 & 16.4 & 34.0 & 4.0 & 15.4 & 3.2 & 0.9 & 3.0 & 0.4 & 2.3 & 0.5 & 1.4 & 0.2 & 1.1 & 0.2 & 12.3 & 95.1 \\
\hline Kiya & iron. & 16 & 16.9 & 34.7 & 4.0 & 17.1 & 3.8 & 1.0 & 3.6 & 0.5 & 2.7 & 0.6 & 1.5 & 0.2 & 1.3 & 0.3 & 14.0 & 102.1 \\
\hline Kiya & ir.-b. silt. & 14 & 17.2 & 38.2 & 4.4 & 16.3 & 3.3 & 0.9 & 3.4 & 0.5 & 2.8 & 0.6 & 1.6 & 0.2 & 1.6 & 0.2 & 14.9 & 106.0 \\
\hline Ilek & sand. & 12 & 14.4 & 31.2 & 3.7 & 13.9 & 2.6 & 0.8 & 2.5 & 0.4 & 2.2 & 0.5 & 1.4 & 0.2 & 1.1 & 0.2 & 11.8 & 86.7 \\
\hline Ilek & grit. & 11 & 18.2 & 38.3 & 4.1 & 15.8 & 4.5 & 0.8 & 3.4 & 0.5 & 2.7 & 0.5 & 1.6 & 0.3 & 1.2 & 0.2 & 13.9 & 106.0 \\
\hline Ilek & silt. & 10 & 20.0 & 48.7 & 5.5 & 19.2 & 4.5 & 1.1 & 4.6 & 0.7 & 3.7 & 0.8 & 2.1 & 0.3 & 2.0 & 0.3 & 22.5 & 136.0 \\
\hline Ilek & iron. & 9 & 22.3 & 50.1 & 5.6 & 20.5 & 5.0 & 1.0 & 4.6 & 0.6 & 3.8 & 0.8 & 2.0 & 0.3 & 2.0 & 0.3 & 20.2 & 139.1 \\
\hline Ilek & iron. & 8 & 22.7 & 50.7 & 5.8 & 21.0 & 5.2 & 1.0 & 4.7 & 0.7 & 3.9 & 0.8 & 2.1 & 0.3 & 2.1 & 0.3 & 19.5 & 140.8 \\
\hline Ilek & silt. & 7 & 22.5 & 48.0 & 5.7 & 21.3 & 4.9 & 1.2 & 4.8 & 0.7 & 3.8 & 0.8 & 2.1 & 0.3 & 1.8 & 0.3 & 20.2 & 138.4 \\
\hline Ilek & silt. & 6 & 22.4 & 47.9 & 5.7 & 21.4 & 4.8 & 1.2 & 4.8 & 0.7 & 3.8 & 0.8 & 2.1 & 0.3 & 1.8 & 0.3 & 20.4 & 138.3 \\
\hline Ilek & calc. & 5 & 17.1 & 36.5 & 4.0 & 14.8 & 3.3 & 0.8 & 3.5 & 0.5 & 2.7 & 0.6 & 1.8 & 0.3 & 1.5 & 0.2 & 17.1 & 104.8 \\
\hline Ilek & sand. & 4 & 19.5 & 41.5 & 5.1 & 19.4 & 4.2 & 1.0 & 4.2 & 0.6 & 3.4 & 0.8 & 1.9 & 0.3 & 1.7 & 0.3 & 18.2 & 122.2 \\
\hline Ilek & silt. & 3 & 22.4 & 48.3 & 5.5 & 20.6 & 4.8 & 1.1 & 4.7 & 0.6 & 3.7 & 0.8 & 2.0 & 0.3 & 1.9 & 0.3 & 20.1 & 137.1 \\
\hline Ilek & ir.-b. silt. & 2 & 23.4 & 48.6 & 5.6 & 20.7 & 4.5 & 1.0 & 4.6 & 0.7 & 3.9 & 0.7 & 2.2 & 0.3 & 2.0 & 0.3 & 19.8 & 138.4 \\
\hline Ilek & sand. & 1 & 18.9 & 39.5 & 4.8 & 17.4 & 4.0 & 1.1 & 4.0 & 0.6 & 3.1 & 0.7 & 1.8 & 0.3 & 1.6 & 0.2 & 15.4 & 113.3 \\
\hline
\end{tabular}

Note: bdl-below detection limit; Form.—stratigraphic formation; silt.—siltstone; iron.—ironstone; ir.-b. silt.-iron-bearing siltstone; sand.-sandstone; grit.-gritstone; calc.—calcareous concretion.

Geochemical proxies reflect changing sedimentation conditions (Figure 7, Table 2) [63-65]. The Mo EF (enrichment factor) and U EF values do not exceed 2.5. Mo EF is greater than 1 in calcareous siltstones of the Kiya Formation. The ironstone layers exhibit a slight increase in proxies of the bioproductivity (P EF, Cu EF). The P EF and $\mathrm{Cu}$ EF values exceed 1 in the intervals of iron-bearing rocks with siderite. Proxies of the paleosalinity ( $\mathrm{Sr} / \mathrm{Ba}$ and $\mathrm{Ca} /(\mathrm{Ca}+\mathrm{Fe}))$ increase at two intervals. The $\mathrm{Sr} / \mathrm{Ba}$ ratio may vary from 0.8 to 1.2. These two layers also exhibit changes in paleoclimate proxies (CIA (Chemical Index of Alteration) and $\mathrm{Sr} / \mathrm{Cu}$ ). CIA increases to 70.9 in siltstones at the top of the Ilek Formation, while $\mathrm{Sr} / \mathrm{Cu}$ decreases to 6.5. Proxies of sedimentation influx (Ti EF, Si EF) have relative maximum values of 1.4-1.5 and 1.0-1.3, respectively, in sandstones of the Ilek Formation and gritstones of the Kiya Formation. The Mn EF increases to 5.2-6.9 and is up to 2.2 in ironstones and siltstones containing carbonates of the Ilek Formation, respectively. 
Table 4. Calculated geochemical proxies, indices, and parameters of the studied samples.

\begin{tabular}{|c|c|c|c|c|c|c|c|c|c|c|c|c|c|c|c|c|c|c|c|}
\hline Form. & Rock & Sample & LREE/HREE & $\mathrm{Ce}^{*}$ & $\mathrm{Eu}^{*}$ & $\mathbf{Y}_{\mathrm{sn}} / \mathrm{Ho}_{\mathrm{sn}}$ & U/Th & Mo EF & U EF & $\mathrm{Sr} / \mathrm{Ba}$ & $\begin{array}{c}\mathrm{Ca} / \\
(\mathrm{Ca}+\mathrm{Fe})\end{array}$ & $\mathrm{Cu} \mathrm{EF}$ & P EF & $\mathrm{Sr} / \mathrm{Cu}$ & CIA & Fe EF & Mn EF & Ti EF & Si EF \\
\hline Kiya & silt. & 20 & 12.5 & 1.0 & 1.4 & 0.9 & 2.9 & 0.5 & 1.2 & 0.2 & 0.1 & 0.3 & 0.7 & 12.9 & 78.4 & 1.6 & 3.9 & 1.1 & 0.9 \\
\hline Kiya & iron. & 16 & 11.3 & 1.0 & 1.3 & 0.8 & 1.6 & 0.7 & 0.8 & 0.2 & 0.0 & 0.4 & 1.2 & 10.2 & 78.5 & 3.4 & 6.9 & 1.2 & 1.0 \\
\hline Kiya & ir.-b. & 14 & 11.3 & 1.0 & 1.3 & 1.0 & 1.6 & 2.5 & 0.6 & 0.2 & 0.1 & 0.6 & 0.8 & 6.6 & 77.8 & 2.0 & 5.2 & 1.1 & 0.9 \\
\hline Ilek & sand. & 12 & 11.8 & 1.0 & 1.5 & 0.9 & 1.5 & 0.3 & 0.5 & 0.4 & 0.5 & 0.4 & 0.8 & 32.7 & 63.2 & 0.7 & 0.4 & 0.9 & 1.3 \\
\hline Ilek & grit. & 11 & 12.2 & 1.0 & 1.0 & 1.0 & 1.7 & 0.5 & 0.7 & 0.1 & 0.8 & 1.2 & 0.9 & 16.8 & 40.2 & 0.6 & 1.0 & 1.5 & 1.3 \\
\hline Ilek & silt. & 10 & 10.3 & 1.1 & 1.2 & 1.1 & 1.3 & 0.7 & 0.7 & 0.8 & 0.4 & 1.6 & 0.7 & 6.5 & 70.9 & 1.2 & 0.7 & 1.4 & 0.9 \\
\hline Ilek & iron. & 9 & 11.1 & 1.0 & 1.0 & 0.9 & 1.1 & 0.5 & 0.6 & 0.6 & 0.3 & 1.5 & 1.0 & 7.5 & 62.5 & 3.4 & 1.1 & 1.3 & 0.9 \\
\hline Ilek & iron. & 8 & 10.9 & 1.0 & 1.0 & 1.0 & 1.0 & 0.0 & 0.6 & 0.6 & 0.3 & 1.4 & 0.8 & 7.9 & 60.8 & 3.6 & 1.1 & 1.4 & 0.9 \\
\hline Ilek & silt. & 7 & 11.1 & 1.0 & 1.2 & 0.9 & 1.2 & 0.4 & 0.6 & 0.7 & 0.6 & 0.9 & 0.7 & 12.9 & 63.1 & 0.8 & 0.6 & 1.3 & 0.9 \\
\hline Ilek & silt. & 6 & 11.2 & 1.0 & 1.2 & 1.0 & 1.2 & 0.4 & 0.6 & 0.8 & 0.5 & 0.9 & 0.8 & 13.3 & 64.1 & 0.8 & 0.5 & 1.3 & 1.0 \\
\hline Ilek & calc. & 5 & 10.6 & 1.0 & 1.2 & 1.1 & 1.3 & 0.5 & 0.7 & 1.2 & 0.9 & 1.1 & 1.1 & 17.2 & 25.1 & 1.0 & 2.2 & 1.2 & 1.0 \\
\hline Ilek & sand. & 4 & 10.7 & 1.0 & 1.2 & 0.9 & 1.6 & 0.4 & 0.7 & 0.9 & 0.5 & 0.7 & 0.8 & 18.4 & 61.6 & 1.0 & 0.6 & 1.4 & 1.0 \\
\hline Ilek & silt. & 3 & 11.2 & 1.0 & 1.1 & 0.9 & 1.1 & 0.5 & 0.6 & 0.7 & 0.5 & 1.0 & 0.8 & 10.8 & 62.3 & 1.0 & 1.1 & 1.3 & 0.9 \\
\hline Ilek & ir.-b. & 2 & 10.7 & 1.0 & 1.1 & 1.0 & 0.9 & 0.6 & 0.5 & 0.9 & 0.5 & 1.5 & 0.8 & 6.7 & 54.1 & 1.6 & 1.9 & 1.2 & 0.8 \\
\hline Ilek & sand. & 1 & 10.9 & 1.0 & 1.3 & 0.9 & 1.5 & 0.5 & 0.6 & 0.7 & 0.5 & 0.6 & 1.0 & 24.9 & 64.3 & 1.1 & 0.6 & 1.5 & 1.1 \\
\hline
\end{tabular}

Note: bdl-below detection limit; Form.—stratigraphic formation; silt.—siltstone; iron.-ironstone; ir.-b.-iron-bearing siltstone; sand.-sandstone; grit.-gritstone; calc.—calcareous concretion. 
Redox-sensitive proxies (Mo EF, U EF, U/Th) indicate a slight depletion of oxygen during the deposition of siltstones. Proxies of the paleosalinity correspond to siltstones with carbonates or pyrite in the Ilek Formation. These proxies change by the reduced $\mathrm{CIA}$ and slightly elevated $\mathrm{Sr} / \mathrm{Cu}$ at the base of the Kiya Formation. The Fe EF and Mn EF vary simultaneously but remain at the average concentrations of bulk continental crust level $[62,66]$ in calcareous siltstones of the Ilek Formation. The Fe EF in iron-bearing rocks varies from 1.5 to 3.6 .

Three groups of elements can be distinguished among the trace metals in ironstones and terrigenous rocks of studied strata based on their distribution (Figure 8). The first group comprising the iron-bearing rocks shows enrichment of $\mathrm{Ba}, \mathrm{Sb}, \mathrm{As}$, and $\mathrm{Ag}$ compared with the average contents in the earth's upper continental crust (UCC) $[62,66]$. The second group displays lower contents of $\mathrm{Cr}, \mathrm{Ni}, \mathrm{Zr}, \mathrm{Hf}, \mathrm{Th}, \mathrm{Sn}, \mathrm{Cs}, \mathrm{W}$, and Tl than those of UCC. The third group $(\mathrm{Co}, \mathrm{Cu}, \mathrm{Sr}, \mathrm{Nb}, \mathrm{Mo}, \mathrm{Ta}, \mathrm{Pb}, \mathrm{Bi}$, and $\mathrm{U})$ has abundances in iron-bearing rocks that are similar to UCC. Ironstones of the Chulym-Yenisey basin are distinguished by the higher content of $\mathrm{Ba}$ and lower contents of $\mathrm{Cr}, \mathrm{Zn}, \mathrm{Mo}, \mathrm{Bi}$, Th, $\mathrm{U}$, and $\mathrm{Sb}$ compared to marine ooidal ironstones of the Bakchar deposit in Western Siberia (Figure 8).

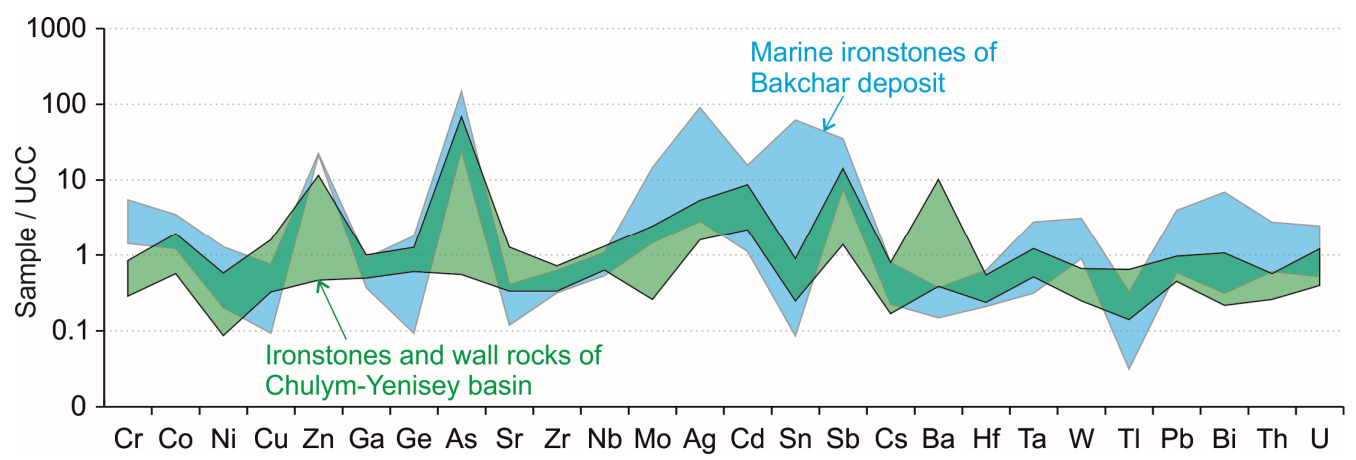

Figure 8. Upper Continental Crust (UCC)-normalized multi-element spider diagram (areas represent the minimum and maximum values) for ironstones and wall rocks of the Chulym-Yenisei basin $[62,66]$. Data of the Bakchar marine ironstone deposit are plotted for comparison [47].

The average content of REY in the Cretaceous sedimentary deposits of the ChulymYenisey basin is 87-141 ppm, less than the average content of the post-Archean Australian shale (PAAS). The low content of REY in studied samples clearly distinguishes them from the Bakchar marine ironstone deposit (Figure 9). The absence of the $\mathrm{Ce}^{*}$ and the positive $\mathrm{Eu}^{*}$ are also characteristic of the studied sediments.

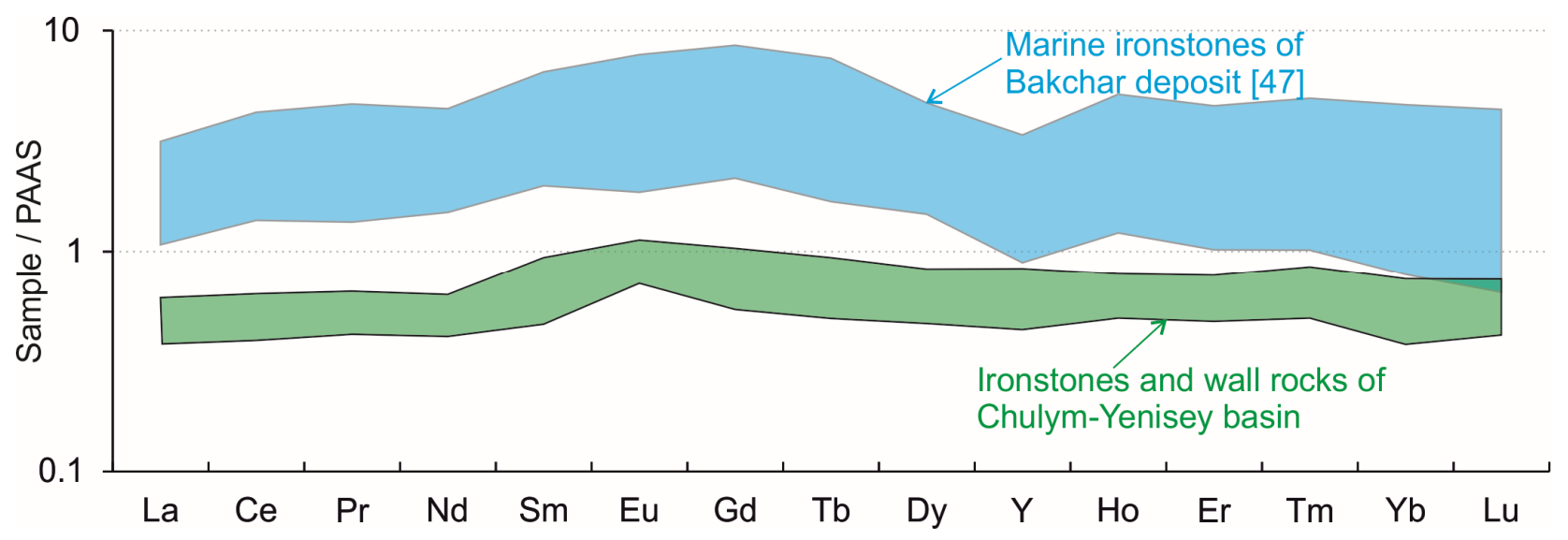

Figure 9. Post-Archean Australian shale (PAAS)-normalized REE-Y (REY) patterns of Upper Cretaceous iron-bearing sediments within the Chulym-Yenisei basin (areas represent the minimum and maximum values) compared with marine ironstones from the Bakchar deposit [47]. Normalization factors are from published data [66]. 
The $\delta^{13} \mathrm{C}$ and $\delta^{18} \mathrm{O}$ values of the carbonate-bearing samples in the studied area display ranges from $-5.4 \%$ to $-12.6 \%$ V-PDB and $-11.2 \%$ to $-15.0 \%$ V-PDB, respectively. The siderite and calcite of the Ilek Formation exhibit $\delta^{13} \mathrm{C}$ ratios from $\sim-5.4$ to $-6.7 \%$ o-PDB and $\delta^{18} \mathrm{O}$ ratios from $-11.2 \%$ to $-11.7 \%$ V-PDB. Carbonate samples of the Kiya Formation of the Shestakovo area show $\delta^{13} \mathrm{C}$ ratios from $-7.1 \%$ to $-12.6 \%$ V-PDB and $\delta^{18} \mathrm{O}$ ratios from $-12.8 \%$ to $-15.0 \%$ V-PDB.

\section{Discussion}

\subsection{Metal Sources of the Chulym-Yenisey Deposits and West-Siberian Iron-Ore Basin}

The Chulym-Yenisey depression in the West Siberian plate is distinctive from similar basins because of its paleogeographic conditions [36]. The epicontinental basin of the ancient West Siberian Sea [67-69] occupied a large area of Western Siberia during the Upper Mesozoic. A continental environment with a well-developed hydrographic network prevailed within the Chulym-Yenisei depression at that time [36,38,69]. Marine ooidal ironstone deposits accumulated across the eastern and southeastern shallow marine zones: Bakchar, Kolpashevo, Laskinsk, Kargasok, Eloguy-Turukhansk, Kulundinsk [39,48,49,70,71]. Previous studies considered that weathered magmatic and metamorphic rocks of the Altai-Sayan mountain region and the Yenisey ridge adjacent to the West Siberian plate represented the source of iron to the basin $[39,70,72,73]$. Alternately, the presence of iron was linked to the transfer from the ancient river system and precipitation in the zone of mixing of acidic river waters with alkaline sea waters. A few researchers [6,74-77] considered the ironstone deposits as a product of low-temperature seeps with mobilization of iron-saturated fluids into the ancient seabed, as described in modern sediments. Therefore, depositional conditions of continental ironstones of the Chulym-Yenisey depression, which is contemporaneous with the West Siberian iron ore basin, remain unexplored.

The mineralogical and geochemical data of the studied iron-bearing strata (Table 5) indicate different metal sources for these regions. The most suitable source for the deposits is the adjacent mountainous Altai-Sayan region which includes the volcanic rocks, basic and felsic magmatic complexes [50,51]. Angular and sub-rounded fragments of quartz and feldspars, the presence of heavy detrital minerals (zircon, monazite, ilmenite) in sediments and the rare earth elements pattern, including positive europium anomaly, supports this interpretation. We infer the late Caledonian volcanogenic rocks of the AltaiSayan region $[50,51]$ as the main iron source. The weathering of iron-bearing minerals in these provinces could have served as primary iron sources.

Table 5. Main features of studied continental ironstones of the Chulym-Yenisei depression and marine ironstones of the West Siberian basin $[39,47,48]$.

\begin{tabular}{|c|c|c|}
\hline $\begin{array}{c}\text { Ironstones } \\
\text { Main Features }\end{array}$ & Ironstones of the Chulym-Yenisei Depression & Bakchar Iron Ore Deposit of the West Siberian Basin \\
\hline Stratigraphy, formations & Early and Late Cretaceous, Ilek and Kiya Formations & $\begin{array}{c}\text { Late Cretaceous and Early Paleogene, Ipatovo, Slavgorod, } \\
\text { Gan'kino, and Lyulinvor Formations }\end{array}$ \\
\hline Facies, environment & $\begin{array}{c}\text { Facies: Fluvial channel and floodplain-lacustrine-boggy } \\
\text { facies } \\
\text { Environment: river system }\end{array}$ & $\begin{array}{l}\text { Facies: coastal and shallow marine facies } \\
\text { Environment: epicontinental sea }\end{array}$ \\
\hline Morphology of ironstone bodies & Layers and lenses with thickness $0.5-1.5 \mathrm{~m}$ & Horizons and seems with thickness of 2-20 m \\
\hline Structure of ironstones & Fine laminated and non-laminated & Ooidal and peloidal \\
\hline \multicolumn{3}{|c|}{ Mineral composition: } \\
\hline Authigenic minerals & $\begin{array}{l}\text { Main: siderite, calcite, chlorite group } \\
\text { Minor: goethite, pyrite, dolomite } \\
\text { Rare: barite }\end{array}$ & $\begin{array}{l}\text { Main: goethite, berthierine, siderite, chamosite, glauconite } \\
\text { Minor: pyrite, monazite, lepidocrocite } \\
\text { Rare: wurtzite, galena, barite, pyrrhotite, greigite, etc. }\end{array}$ \\
\hline Detrital minerals & $\begin{array}{l}\text { Main: quartz, feldspars } \\
\text { Minor: zircon, monazite, ilmenite } \\
\text { Rare: rutile, magnetite, hematite, silver }\end{array}$ & $\begin{array}{l}\text { Main: quartz } \\
\text { Minor: feldspars, epidote, zircon, monazite, ilmenite } \\
\text { Rare: rutile, magnetite, titanomagnetite, hornblende }\end{array}$ \\
\hline \multicolumn{3}{|c|}{ Geochemical specifics: } \\
\hline Enrichment & $\mathrm{Ba}, \mathrm{Sb}, \mathrm{Cd}, \mathrm{As}, \mathrm{Ag}, \mathrm{Zn}$, positive $\mathrm{Eu}^{*}$ & As, Zn, Pb, Bi, Sb, Ag, Co, $\underset{\mathrm{Ce}^{*}}{\mathrm{Cr}}$, Th, U, W, Cd, REY, positive \\
\hline Depletion & $\begin{array}{c}\mathrm{Cr}, \mathrm{Ni}, \mathrm{Ga}, \mathrm{Ge}, \mathrm{Zr}, \mathrm{Mo}, \mathrm{Sn}, \mathrm{Cs}, \mathrm{Hf}, \mathrm{Ta}, \mathrm{W}, \mathrm{Tl}, \mathrm{Pb}, \mathrm{Bi}, \mathrm{Th}, \mathrm{U}, \\
\text { REY }\end{array}$ & $\mathrm{Ni}, \mathrm{Cu}, \mathrm{Ga}, \mathrm{Ge}, \mathrm{Sr}, \mathrm{Zr}, \mathrm{Cs}, \mathrm{Ba}, \mathrm{Hf}, \mathrm{Tl}$ \\
\hline
\end{tabular}




\subsection{Depositional and Diagenetic Conditions}

Thin layers of ironstones in the Cretaceous strata of the Chulym-Yenisei depression are confined to siltstone deposits, which indicates iron immobilization within the environment of meromictic waters [18]. This environment promotes the accumulation of ironstones in the floodplain-lacustrine-boggy facies. The presence of siderite and chamosite within ironstones indicates oxygen-depleted porewater conditions of the mineral formation. Stable isotope composition of studied siderite and calcite $\left(\delta^{13} \mathrm{C}-5.4\right.$ to $-12.6 \% \mathrm{~V}-\mathrm{PDB}$ and $\delta^{18} \mathrm{O}-11.2 \%$ to $-15.0 \%$ V-PDB) indicate continental freshwater limestones [78]. Carbon dioxide produced by the bacterial decomposition of organic matter contributed to the concentration of carbonate minerals and possible iron concentration. Depleted carbon isotope ratios $(-12.6 \% \mathrm{~V}-\mathrm{PDB})$ indicate bacterial carbon dioxide production [79]. Calcite, siderite, and aragonite formed within the ferruginous lakes depending on the depositional conditions [18].

Association of calcite and aragonite (Figure 6) in sedimentary rocks reflects two possible mechanisms: (i) sequential precipitation of calcite and aragonite or (ii) conversion of aragonite to calcite. The co-occurrence of minerals (Figure 6) in some grains excludes their sequential precipitation in these cases. A diagenetic process in an aqueous environment with an admixture of $\mathrm{Mg}$ and/or biomolecules [80-82] led to the transformation of aragonite to calcite. This transformation was the predominant mechanism leading to the formation calcite-aragonite microaggregates (Figure 6). For example, these features in the sedimentary environment were documented in hot spring travertines [83]. Siderite was transformed to goethite with the active participation of humic acids with the local formation of hydroxyapatite in lacustrine-bog conditions [84]. The occasional presence of pyrite framboids in siltstones suggests the local saturation of the pore water with sulfide ions due to bacterial sulfate reduction [85]. The interaction of sulfide ions with reactive iron led to the formation of pyrite framboids below the water-sediment interface, which is rarely recorded in freshwater environments $[18,86,87]$, including basal loams of peat bogs $[88,89]$. The accumulation of siltstones with ironstones took place at the bottom of swampy lakes. Layers with carbonates are indicators of the mesotrophic and eutrophic conditions at the bottom of lakes. Subsequent diagenetic reduction of mineral phases promoted iron transfer [73] to the coastal-channel facies, where metal oxidation could occur with partial accumulation of chamosite.

The mobilized iron was primarily precipitated in the meromictic waters of lakes and bogs in the area of the paleo-river system that coincides with the modern Kiya river. The organic matter decomposition resulted in the production of carbon dioxide and/or sulfide ions and the formation of carbonates or pyrite. During the diagenetic transformation with the additional input of ferric oxide water, part of the iron was immobilized under sub-oxic to oxic conditions within floodplain lacustrine to coastal channel facies, which contributed to the accumulation of ferruginous phyllosilicates and/or goethite.

\subsection{Paleo-Environmental Conditions}

The elevated enrichment factors for Fe and Mn suggest immobilization of these metals in the biogeochemical cycle of the river system as authigenic mineral formation. Iron concentrates as carbonate (siderite), phyllosilicate (chamosite), or hydroxide (hydrogoethite). Moreover, hydrogoethite probably forms as precipitates in an oxidic aqueous environment by diagenetic alteration of siderite and by the oxidation of chamosite. An enrichment of Fe EF and Mn EF is accompanied by enhanced bioproductivity ( $\mathrm{Cu}$ EF and $\mathrm{P} E F$ ) proxies, suggesting organic matter decomposition and generation of $\mathrm{HCO}_{3}{ }^{2-}$. These processes facilitated the predominance of carbonates as the authigenic minerals.

The variation of the sedimentation flux proxies (Ti EF, $\mathrm{Si} \mathrm{EF}$ ) for the deposits preceding the carbonate layers indicates periods of flooding and the subsequent development of the bog-lacustrine environment. Paleo-salinity proxies $(\mathrm{Sr} / \mathrm{Ba}$ and $\mathrm{Ca} /(\mathrm{Ca}+\mathrm{Fe}))$ of the sedimentation environment reflect weak aridization and reduced weathering. Siltstones at the top of the Ilek Formation accumulated under conditions of humidization and weak 
weathering, revealed by the changes in $\mathrm{Sr} / \mathrm{Cu}$ and CIA, respectively. The environment was favorable for the accumulation of organic matter. Changes in environmental conditions correspond to the transgression of the West Siberian Sea [36] and the humidification of climate in the Chulym-Yenisey depression.

The sedimentary record of the Ilek and Kiya Formations [34,90] includes known oceanic anoxic events [91-93], such as the Early Aptian anoxia (OAE Ia) and CenomanianTuronian anoxia (OAE 2). A relationship was established between the hypoxia of the bottom water and global oceanic anoxia during the Cretaceous period in coeval marine ooidal ironstone deposits in Western Siberia [47]. The global geological events possibly influenced regional geological processes within the Chulym-Yenisey basin. This could be expressed in an increase in bioproductivity and mobilization of nutrients, humidification, and increased weathering of the magmatic rocks of the Kuznetsk Alatau as a result of OAE Ia and/or OAE $2[29,32,94,95]$.

\section{Conclusions}

Detailed petrographical, mineralogical, and geochemical studies made it possible to highlight the following conclusions.

1. Continental sediments of Cretaceous Ilek and Kia Formations of the Chulym-Yenisei depression consist of two lithofacies: (i) cross-stratified litho-feldspatho-quartzose sandstones and siltstones and (ii) bluish-gray siltstones with ironstones. These two facies document fluvial channel and floodplain-lacustrine-boggy deposits, respectively. Thin layers of ironstones within siltstones indicate deposition in meromictic waters.

2. The detrital minerals of studied deposits are represented by quartz and feldspars. The main iron-rich authigenic minerals of ironstones are chlorite group (possible chamosite), goethite, siderite, pyrite, nontronite, and illite. Non-iron minerals are kaolinite, beidellite, aragonite, dolomite, calcite, apatite, and barite. Local bacterial sulfate reduction led to the formation of pyrite framboids in siltstone layers. The subsequent diagenetic iron reduction, induced by microbial activity, promoted iron diffusion transfer and the formation of chamosite. Goethite precipitated in an aqueous system due to the additional input iron-rich water.

3. The changes in geochemical proxies in the studied Cretaceous sequence demonstrate fluctuations in paleoenvironmental conditions. Siltstones accumulated under humid conditions, while sandstones were deposited in weakly arid conditions. This could be linked with iron mobilization due to increased weathering of the rocks of the Kuznetsk Alatau as a possible result of intense humidification during oceanic anoxic events.

4. During the Cretaceous, the Chulym-Yenisey depression was a part of a distinctive continental environment, unlike the West Siberian plate, where marine ooidal ironstones were deposited. Most irons within the Chulym-Yenisey depression were supplied from the Altai-Sayan mountainous region. Mineralogical and geochemical characteristics of these ironstones are clearly distinguished, indicating different iron sources for the Chulym-Yenisey basin and the ancient West Siberian Sea.

Author Contributions: M.R. conceived and designed the study; M.R., A.D. and A.R. performed the laboratory investigations; M.R. and S.B. analyzed the data; M.R. and A.R. contributed materials; M.R. and S.B. wrote the paper. All authors have read and agreed to the published version of the manuscript.

Funding: The study was supported by the Russian Science Foundation (20-77-00007).

Data Availability Statement: Not applicable.

Acknowledgments: Analytical studies were performed using the equipment acquired within the framework of the Tomsk Polytechnic University Competitiveness Enhancement Program. The authors are thankful to the editor and five anonymous reviewers for their careful reading, constructive criticisms, and valuable suggestions on the manuscript.

Conflicts of Interest: The authors declare no conflict of interest. 


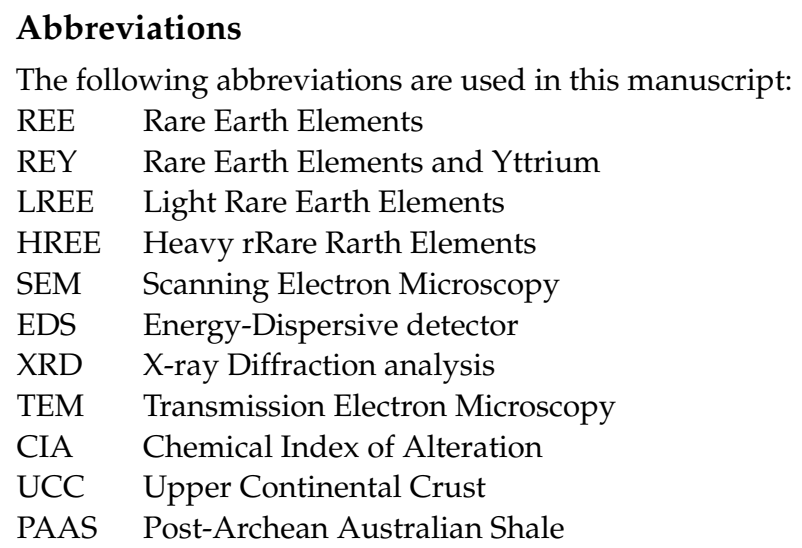

\section{References}

1. Van Houten, F.B. Review of Cenozoic ooidal ironstones. Sediment. Geol. 1992, 78, 101-110. [CrossRef]

2. Van Houten, F.B.; Bhattacharyya, D.P. Phanerozoic Oolitic Ironstones-Geologic Record and Facies Model. Annu. Rev. Earth Planet. Sci. 1982, 10, 441-457. [CrossRef]

3. Young, T.P. Phanerozoic ironstones: An introduction and review. Geol. Soc. Lond. Spec. Publ. 1989, 46, ix-xxv. [CrossRef]

4. Taylor, W.E.G. SEDIMENTARY ROCKS I Ironstones. In Encyclopedia of Geology; Harper \& Row: New York, NY, USA, 2005; pp. 97-107. ISBN 9780123693969.

5. Petranek, J.; Van Houten, F.B. Phanerozoic Ooidal Ironstones. Czech Geol. Surv. Spec. Pap. 1997, 7, 4-71.

6. Kimberley, M.M. Exhalative origins of iron formations. Ore Geol. Rev. 1989, 5, 13-145. [CrossRef]

7. Van Houten, F.B. Search for Milankovitch patterns among oolitic ironstones. Paleoceanography 1986, 1, 459-466. [CrossRef]

8. Van Houten, F.B.; Arthur, M.A. Temporal patterns among Phanerozoic oolitic ironstones and oceanic anoxia. Geol. Soc. Spec. Publ. 1989, 46, 33-49. [CrossRef]

9. Kimberley, M.M. Debate about ironstone: Has solute supply been surficial weathering, hydrothermal convection, or exhalation of deep fluids? Terra Nova 1994, 6, 116-132. [CrossRef]

10. Kimberley, M.M. Origin of Oolitic Iron Formations. SEPM J. Sediment. Res. 1979, 49, 111-131. [CrossRef]

11. Kholodov, V.N.; Nedumov, R.I.; Golubovskaya, E.V. Facies types of sedimentary iron ore deposits and their geochemical features: Communication 2. Problems of the geochemistry of phanerozoic iron ores. Lithol. Miner. Resour. 2013, 48, 14-47. [CrossRef]

12. Mücke, A. Chamosite, siderite and the environmental conditions of their formation in chamosite-type Phanerozoic ooidal ironstones. Ore Geol. Rev. 2006, 28, 235-249. [CrossRef]

13. Müller, G.; Förstner, U. Recent iron ore formation in Lake Malawi, Africa. Miner. Depos. 1973, 8, 278-290. [CrossRef]

14. Rohrlich, V. Microstructure and microchemistry of iron ooliths. Miner. Depos. 1974, 9, 133-142. [CrossRef]

15. Golubovskaya, E.V. Geochemistry of oolitic iron ores of different facies in the northern Aral region. Lithol. Miner. Resour. 2005, 40, 187-190. [CrossRef]

16. Morris, R.C.; Ramanaidou, E.R. Genesis of the channel iron deposits (CID) of the Pilbara region, Western Australia. Aust. J. Earth Sci. 2007, 54, 733-756. [CrossRef]

17. Bekker, A.; Kovalick, A. Ironstones, Iron Formations, and Iron Ore. In Reference Module in Earth Systems and Environmental Sciences; Elsevier: Amsterdam, The Netherlands, 2020.

18. Swanner, E.D.; Lambrecht, N.; Wittkop, C.; Harding, C.; Katsev, S.; Torgeson, J.; Poulton, S.W. The biogeochemistry of ferruginous lakes and past ferruginous oceans. Earth-Sci. Rev. 2020, 211, 103430. [CrossRef]

19. Rudmin, M.; Kalinina, N.; Banerjee, S.; Reva, I.; Kondrashova, E.; Kanaki, A.; Trubin, Y.; Baldermann, A.; Mazurov, A. Origin of Oligocene channel ironstones of Lisakovsk deposit (Turgay depression, northern Kazakhstan). Ore Geol. Rev. 2021, 104391. [CrossRef]

20. Formozova, L.N. Iron Ores in the Northern Aral Region; USSR Academy Science: Moskow, Russia, 1959.

21. Yanitskiy, A.L. Oligocene Oolitic Iron Ores of Northern Turgai and Its Genesis; AN USSR: Moscow, Russia, 1960.

22. Ramanaidou, E.R.; Morris, R.C.; Horwitz, R.C. Channel iron deposits of the Hamersley Province, Western Australia. Aust. J. Earth Sci. 2003, 50, 669-690. [CrossRef]

23. Dalstra, H.J.; Gill, T.; Faragher, A.; Scott, B.; Kakebeeke, V. Channel iron deposits, a major new district around the Caliwingina Creek, central Hamersley Ranges, Western Australia. Trans. Inst. Min. Metall. Sect. B Appl. Earth Sci. 2010, 119, 12-20. [CrossRef]

24. McGregor, F.; Ramanaidou, E.; Wells, M. Phanerozoic ooidal ironstone deposits—generation of potential exploration targets. Appl. Earth Sci. 2010, 119, 60-64. [CrossRef]

25. Simonson, B.M.; Schubel, K.A.; Hassler, S.W. Carbonate sedimentology of the early Precambrian Hamersley Group of Western Australia. Precambrian Res. 1993, 60, 287-335. [CrossRef]

26. Bodor, S.; Polgári, M.; Szentpétery, I.; Földessy, J. Microbially mediated iron ore formation, Silicic Superunit, Rudabánya, Hungary. Ore Geol. Rev. 2016, 72, 391-401. [CrossRef] 
27. Haest, M.; Cudahy, T.; Laukamp, C.; Gregory, S. Quantitative mineralogy from infrared spectroscopic data. II. Three-dimensional mineralogical characterization of the rocklea channel iron deposit, Western Australia. Econ. Geol. 2012, 107, 229-249. [CrossRef]

28. Haest, M.; Cudahy, T.; Laukamp, C.; Gregory, S. Quantitative mineralogy from infrared spectroscopic data. I. Validation of mineral abundance and composition scripts at the rocklea channel iron deposit in Western Australia. Econ. Geol. 2012, 107, 209-228. [CrossRef]

29. Schmitz, B.; Pujalte, V. Sea-level, humidity, and land-erosion records across the initial Eocene thermal maximum from a continental-marine transect in northern Spain. Geology 2003, 31, 689-692. [CrossRef]

30. Jenkyns, H.C. Cretaceous anoxic events: From continents to oceans. J. Geol. Soc. 1980, 137, 171-188. [CrossRef]

31. Weijers, J.W.H.; Schouten, S.; Sluijs, A.; Brinkhuis, H.; Sinninghe Damsté, J.S. Warm arctic continents during the PalaeoceneEocene thermal maximum. Earth Planet. Sci. Lett. 2007, 261, 230-238. [CrossRef]

32. Poulton, S.W.; Henkel, S.; März, C.; Urquhart, H.; Flögel, S.; Kasten, S.; Sinninghe Damsté, J.S.; Wagner, T. A continentalweathering control on orbitally driven redox-nutrient cycling during Cretaceous Oceanic Anoxic Event 2. Geology 2015, 43, 963-966. [CrossRef]

33. Brett, C.E.; McLaughlin, P.I.; Histon, K.; Schindler, E.; Ferretti, A. Time-specific aspects of facies: State of the art, examples, and possible causes. Palaeogeogr. Palaeoclimatol. Palaeoecol. 2012, 367-368, 6-18. [CrossRef]

34. Shczepetov, S.V. On Stratigraphy and Flora of Cretaceous Deposits in the Chulym-Yenisei Region, Western Siberia. Stratigr. Geol. Correl. 2018, 26, 474-487. [CrossRef]

35. Akhmetiev, M.A.; Zaporozhets, N.I. Paleogene events in Central Eurasia: Their role in the flora and vegetation cover evolution, migration of phytochore boundaries, and climate changes. Stratigr. Geol. Correl. 2014, 22, 312-335. [CrossRef]

36. Kontorovich, A.E.; Ershov, S.V.; Kazanenkov, V.A.; Karogodin, Y.N.; Kontorovich, V.A.; Lebedeva, N.K.; Nikitenko, B.L.; Popova, N.I.; Shurygin, B.N. Cretaceous paleogeography of the West Siberian sedimentary basin. Russ. Geol. Geophys. 2014, 55, 582-609. [CrossRef]

37. Frieling, J.; Iakovleva, A.I.; Reichart, G.-J.; Aleksandrova, G.N.; Gnibidenko, Z.N.; Schouten, S.; Sluijs, A. Paleocene-Eocene warming and biotic response in the epicontinental West Siberian Sea. Geology 2014, 42, 767-770. [CrossRef]

38. Smith, A.G.; Smith, D.G.; Funnell, B.M. Atlas of Mesozoic and Cenozoic Coastlines; Cambridge University Press: Cambridge, UK, 1994; ISBN 0521451558.

39. Belous, N.C.; Nikolaeva, I.V.; Kazansky, Y.P.; Berdnikov, A.P.; Klyarovskiy, V.M.; Kuznetsov, V.P.; Babin, A.A. The Western-Siberian Iron Ore Basin; Siberian Branch of the Academy of Sciences of the USSR: Novosibirsk, Russia, 1964.

40. Rudmin, M.; Mazurov, A.; Bolsunovskaya, L. Mineral and elemental composition features of "loose" oolitic ores in Bakchar iron ore cluster (Tomsk oblast). In IOP Conference Series: Earth and Environmental Science; IOP Publishing: Bristol, UK, 2014; Volume 21, pp. 1-6. [CrossRef]

41. Rudmin, M.; Banerjee, S.; Mazurov, A.; Makarov, B.; Martemyanov, D. Economic potential of glauconitic rocks in Bakchar deposit (S-E Western Siberia) for alternate potash fertilizer. Appl. Clay Sci. 2017, 150, 225-233. [CrossRef]

42. Rudmin, M.; Reva, I.; Sokol, E.; Abdullayev, E.; Ruban, A.; Kudryavtsev, A.; Tolkachev, O.; Mazurov, A. Minerals of Rare Earth Elements in High-Phosphorus Ooidal Ironstones of the Western Siberia and Turgai Depression. Minerals 2019, 10, 16. [CrossRef]

43. Rudmin, M.A.; Mazurov, A.K.; Reva, I.V.; Stebletsov, M.D. Prospects of integrated development of Bakchar iron deposit (Western Siberia, Russia). Bull. Tomsk Polytech. Univ. Geo Assets Eng. 2018, 329, 85-94.

44. Lipayeva, A.V.; Pavlov, D.I. Subsurface waters and the generation of iron ores in the northern Priaralye. Lithol. Miner. Resour. 1986, 104-117.

45. Pavlov, D.I.; Gorzhevskiy, D.I.; Goleva, G.A.; Kalinko, M.K.; Kartsev, A.A.; Lipayeva, A.V. Conjunction of ore- and oil-forming systems in sedimentary basins and the prediction of ore deposits. Int. Geol. Rev. 1991, 33, 822-829. [CrossRef]

46. Pavlov, D.I. Relationship of sedimentary iron and manganese deposits with petroleum and gas-bearing basins. Geol. Ore Depos. 1989, 31, 80-91.

47. Rudmin, M.; Banerjee, S.; Abdullayev, E.; Ruban, A.; Filimonenko, E.; Lyapina, E.; Kashapov, R.; Mazurov, A. Ooidal ironstones in the Meso-Cenozoic sequences in western Siberia: Assessment of formation processes and relationship with regional and global earth processes. J. Palaeogeogr. 2020, 9, 1. [CrossRef]

48. Rudmin, M.; Mazurov, A.; Banerjee, S. Origin of ooidal ironstones in relation to warming events: Cretaceous-Eocene Bakchar deposit, south-east Western Siberia. Mar. Pet. Geol. 2019, 100, 309-325. [CrossRef]

49. Rudmin, M.; Roberts, A.P.; Horng, C.-S.; Mazurov, A.; Savinova, O.; Ruban, A.; Kashapov, R.; Veklich, M. Ferrimagnetic Iron Sulfide Formation and Methane Venting Across the Paleocene-Eocene Thermal Maximum in Shallow Marine Sediments, Ancient West Siberian Sea. Geochem. Geophys. Geosystems 2018, 19, 21-42. [CrossRef]

50. Buslov, M.M.; Watanabe, T.; Smirnova, L.V.; Fujiwara, I.; Iwata, K.; de Grave, I.; Semakov, N.N.; Travin, A.V.; Kir'yanova, A.P.; Kokh, D.A. Role of strike-slip faults in Late Paleozoic-Early Mesozoic tectonics and geodynamics of the Altai-Sayan and East Kazakhstan folded zone. Geol. I Geofiz. 2003, 44, 49-75.

51. Surkov, V.S. Neogean evolution of the young Ural-Siberian platform. Geol. I Geofiz. 2002, 43, 754-761.

52. Babin, G.A.; Gusev, N.I.; Yuryev, A.A.; Uvarov, A.N.; Dubskiy, V.C.; Chernykh, A.I.; Tchigrev, A.F.; Chusovitina, G.D.; Korableva, T.V.; Kosyakova, L.N.; et al. State Geological Map of the Russian Federation. Scale 1: 1000000. Third Generation. Series: Altai-Sayan. Sheet N-45-Novokuznetsk; VSEGEI: St. Petersburg, FL, USA, 2007. 
53. Averianov, A.O.; Voronkevich, A.V.; Leshchinskiy, S.V.; Fayngertz, A.V. A Ceratopsian dinosaur Psittacosaurus sibiricus from the Early Cretaceous of West Siberia, Russia and its phylogenetic relationships. J. Syst. Palaeontol. 2010, 4, 359-395. [CrossRef]

54. Skutschas, P.P.; Markova, V.D.; Boitsova, E.A.; Leshchinskiy, S.V.; Ivantsov, S.V.; Maschenko, E.N.; Averianov, A.O. The first dinosaur egg from the Lower Cretaceous of Western Siberia, Russia. Hist. Biol. 2017, 31, 836-844. [CrossRef]

55. Leshchinskiy, S.V.; Faingerts, A.V.; Ivantsov, S.V. Bol'shoi Ilek as the Ilek Formation Stratotype of the Lower Cretaceous and a New Dinosaur and Mammoth Fauna Site in the Southeastern Western Siberia. Dokl. Earth Sci. 2019, 488, 1157-1160. [CrossRef]

56. Skutschas, P.; Morozov, S.; Averianov, A.; Leshchinskiy, S.; Ivantsov, S.; Fayngerts, A.; Feofanova, O.; Vladimirova, O.; Slobodin, D. Femoral histology and growth patterns of the ceratopsian dinosaur Psittacosaurus sibiricus from the Early Cretaceous of Western Siberia. Acta Palaeontol. Pol. 2021, 66. [CrossRef]

57. Brumsack, H.-J. The trace metal content of recent organic carbon-rich sediments: Implications for Cretaceous black shale formation. Palaeogeogr. Palaeoclimatol. Palaeoecol. 2006, 232, 344-361. [CrossRef]

58. Tribovillard, N.; Algeo, T.J.; Lyons, T.; Riboulleau, A. Trace metals as paleoredox and paleoproductivity proxies: An update. Chem. Geol. 2006, 232, 12-32. [CrossRef]

59. Price, J.R.; Velbel, M.A. Chemical weathering indices applied to weathering profiles developed on heterogeneous felsic metamorphic parent rocks. Chem. Geol. 2003, 202, 397-416. [CrossRef]

60. Nesbitt, H.W.; Young, G.M. Early Proterozoic climates and plate motions inferred from major element chemistry of lutites. Nature 1982, 299, 715-717. [CrossRef]

61. Mondillo, N.; Boni, M.; Joachimski, M.; Santoro, L. C-O stable isotope geochemistry of carbonate minerals in the nonsulfide zinc deposits of the middle east: A review. Minerals 2017, 7, 217. [CrossRef]

62. Rudnick, R.L.; Gao, S. Composition of the Continental Crust. In Treatise on Geochemistry; Elsevier: Amsterdam, The Netherlands, 2014; pp. 1-51. ISBN 9780080983004.

63. Liu, C.; Liu, K.; Wang, X.; Wu, L.; Fan, Y. Chemostratigraphy and sedimentary facies analysis of the Permian Lucaogou Formation in the Jimusaer Sag, Junggar Basin, NW China: Implications for tight oil exploration. J. Asian Earth Sci. 2019, 178, 96-111. [CrossRef]

64. Zhang, K.; Liu, R.; Liu, Z.; Li, B.; Han, J.; Zhao, K. Influence of volcanic and hydrothermal activity on organic matter enrichment in the Upper Triassic Yanchang Formation, southern Ordos Basin, Central China. Mar. Pet. Geol. 2020, 112, 104059. [CrossRef]

65. Danzelle, J.; Riquier, L.; Baudin, F.; Thomazo, C.; Pucéat, E. Oscillating redox conditions in the Vocontian Basin (SE France) during Oceanic Anoxic Event 2 (OAE 2). Chem. Geol. 2018, 493, 136-152. [CrossRef]

66. Taylor, S.R.; McLennan, S.M. The Continental Crust: Its Composition and Evolution. An Examination of the Geochemical Record Preserved in Sedimentary Rocks; Blackwell: Oxford, UK, 1985; ISBN 0632011483.

67. Iakovleva, A.I. Palynological reconstruction of the Eocene marine palaeoenvironments in south of western Siberia. Acta Palaeobot. 2011, 51, 229-248.

68. Carney, J.P.; Dick, T.A. The historical ecology of yellow perch (Perca flavescens [Mitchill]) and their parasites. J. Biogeogr. 2000, 27, 1337-1347. [CrossRef]

69. Akhmet'ev, M.A.; Zaporozhets, N.I.; Iakovleva, A.I.; Aleksandrova, G.N.; Beniamovsky, V.N.; Oreshkina, T.V.; Gnibidenko, Z.N.; Dolya, Z.A. Comparative analysis of marine paleogene sections and biota from West Siberia and the Arctic Region. Stratigr. Geol. Correl. 2010, 18, 635-659. [CrossRef]

70. Nikolaeva, I.V. Bakchar Oolitic Iron Ore Deposit; Siberian Branch of the Academy of Sciences of the USSR: Novosibirsk, Russia, 1967.

71. Rudmin, M.A.; Mazurov, A.K. Oolitic ores in the Bakchar iron-ore cluster (Tomsk Oblast). Dokl. Earth Sci. 2016, 471, 1238-1241. [CrossRef]

72. Strakhov, N.M. Iron Ore Facies and Their Analogues in the Earth's History: Experience of Historical-Geographical Analysis of Sedimentary Processes. Tr. IGN AN SSSR. Geol. Ser. 1947, 22, 261-267.

73. Kholodov, V.N.; Nedumov, R.I.; Golubovskaya, E.V. Facies types of sedimentary iron ore deposits and their geochemical features: Communication 1. Facies groups of sedimentary ores, their lithology, and genesis. Lithol. Miner. Resour. 2012, 47, 447-472. [CrossRef]

74. Heikoop, J.M.; Tsujita, C.J.; Risk, M.J.; Tomascik, T.; Mah, A.J. Modern iron ooids from a shallow-marine volcanic setting: Mahengetang, Indonesia. Geology 1996, 24, 759-762. [CrossRef]

75. Lemoalle, J.; Dupont, B. Iron-bearing Oolites and the Present Conditions of Iron Sedimentation in Lake Chad (Africa). In Ores in Sediments; Springer: Berlin/Heidelberg, Germany, 1973; pp. 167-178.

76. Sturesson, U.; Heikoop, J.M.; Risk, M.J. Modern and Palaeozoic iron ooids-a similar volcanic origin. Sediment. Geol. 2000, 136, 137-146. [CrossRef]

77. Di Bella, M.; Sabatino, G.; Quartieri, S.; Ferretti, A.; Cavalazzi, B.; Barbieri, R.; Foucher, F.; Messori, F.; Italiano, F. Modern Iron Ooids of Hydrothermal Origin as a Proxy for Ancient Deposits. Sci. Rep. 2019, 9, 7107. [CrossRef] [PubMed]

78. Nelson, C.S.; Smith, A.M. Stable oxygen and carbon isotope compositional fields for skeletal and diagenetic components in New Zealand Cenozoic nontropical carbonate sediments and limestones: A synthesis and review. N. Z. J. Geol. Geophys. 1996, 39, 93-107. [CrossRef]

79. Mozley, P.S.; Wersin, P. Isotopie composition of siderite as an indicator of depositional environment. Geology 1992, 20, 817-820. [CrossRef] 
80. Robert, L. Folk The Natural History Of Crystalline Calcium Carbonate: Effect of Magnesium Content And Salinity. J. Sediment. Res. 1974, 44, 40-53. [CrossRef]

81. Nindiyasari, F.; Griesshaber, E.; Fernández-Díaz, L.; Astilleros, J.M.; Sánchez-Pastor, N.; Ziegler, A.; Schmahl, W.W. Effects of Mg and hydrogel solid content on the crystallization of calcium carbonate in biomimetic counter-diffusion systems. Cryst. Growth Des. 2014, 14, 4790-4802. [CrossRef]

82. Casella, L.A.; Griesshaber, E.; Yin, X.; Ziegler, A.; Mavromatis, V.; Müller, D.; Ritter, A.C.; Hippler, D.; Harper, E.M.; Dietzel, M.; et al. Experimental diagenesis: Insights into aragonite to calcite transformation of Arctica islandica shells by hydrothermal treatment. Biogeosciences 2017, 14, 1461-1492. [CrossRef]

83. Greer, H.F.; Zhou, W.; Guo, L. Phase transformation of Mg-calcite to aragonite in active-forming hot spring travertines. Mineral Petrol. 2015, 109, 453-462. [CrossRef]

84. Xing, B.; Graham, N.; Yu, W. Transformation of siderite to goethite by humic acid in the natural environment. Commun. Chem. 2020, 3, 38. [CrossRef]

85. Rickard, D.; Luther III, G.W. Chemistry of iron sulfides. Chem. Rev. 2007, 107, 514-562. [CrossRef]

86. Suits, N.S.; Wilkin, R.T. Pyrite formation in the water column and sediments of a meromictic lake. Geology 1998, 26, 1099-1102. [CrossRef]

87. Davison, W.; Lishman, J.P.; Hilton, J. Formation of pyrite in freshwater sediments: Implications for C S ratios. Geochim. Et Cosmochim. Acta 1985, 49, 1615-1620. [CrossRef]

88. Rudmin, M.; Wilson, M.J.; Wilson, L.; Savichev, O.; Yakich, T.; Shaldybin, M.; Ruban, A.; Tabakaev, R.; Ibraeva, K.; Mazurov, A. Geochemical and mineralogical features of the substrates of the Vasyugan Mire, Western Siberia, Russia. Catena 2020, 194, 104781. [CrossRef]

89. Rudmin, M.; Ruban, A.; Savichev, O.; Mazurov, A.; Dauletova, A.; Savinova, O. Authigenic and Detrital Minerals in Peat Environment of Vasyugan Swamp, Western Siberia. Minerals 2018, 8, 500. [CrossRef]

90. Golovneva, L.B.; Shchepetov, S.V. Phytostratigraphy of Albian-Cenomanian sediments in the Kiya River basin (the Chulym-Yenisei area of the west Siberian lowland). Stratigr. Geol. Correl. 2010, 18, 153-165. [CrossRef]

91. Jenkyns, H.C. Geochemistry of oceanic anoxic events. Geochem. Geophys. Geosystems 2010, 11, 1-30. [CrossRef]

92. Heimhofer, U.; Wucherpfennig, N.; Adatte, T.; Schouten, S.; Schneebeli-Hermann, E.; Gardin, S.; Keller, G.; Kentsch, S.; Kujau, A. Vegetation response to exceptional global warmth during Oceanic Anoxic Event 2. Nat. Commun. 2018, 9, 3832. [CrossRef]

93. Jenkyns, H.C.; Matthews, A.; Tsikos, H.; Erel, Y. Nitrate reduction, sulfate reduction, and sedimentary iron isotope evolution during the Cenomanian-Turonian oceanic anoxic event. Paleoceanography 2007, 22, 1-17. [CrossRef]

94. Wang, Y.; Huang, C.; Sun, B.; Quan, C.; Wu, J.; Lin, Z. Paleo-CO2 variation trends and the Cretaceous greenhouse climate. Earth-Sci. Rev. 2014, 129, 136-147. [CrossRef]

95. Scholz, F.; Beil, S.; Flögel, S.; Lehmann, M.F.; Holbourn, A.; Wallmann, K.; Kuhnt, W. Oxygen minimum zone-type biogeochemical cycling in the Cenomanian-Turonian Proto-North Atlantic across Oceanic Anoxic Event 2. Earth Planet. Sci. Lett. 2019, 517, 50-60. [CrossRef] 